\title{
Civil Society Organizations for and with the Courts and Judges - Struggle for the Rule of Law and Judicial Independence: The Case of Poland 1976-2020
}

\author{
Łukasz Bojarski ${ }^{1}$ \\ ${ }^{1}$ Faculty of Law, University of Oslo, Oslo, Norway \\ Corresponding author lukasz.bojarski@jus.uio.no
}

(Received 02 October 2021; accepted 04 October 2021)

\begin{abstract}
During the rule of law backsliding crisis in Poland since late 2015, Civil Society Organizations (CSOs) have been active in the struggles to defend judicial independence. CSOs cooperate closely with judges and support their 'judicial resistance'. This Article has three main objectives: describe and analyze the relationship between judges and CSOs; show the evolution - both continuity and discontinuity in their relations over time; assess whether CSOs' activities are of any practical significance and therefore worth attention. The CSO-judicial relationship is analyzed for three periods: 1976-1989, the years before the transformation of Poland from a 'people's republic' to a democracy; 1989-2015, the time of building liberal democracy and the rule of law; 2015-2020, the time of defending the rule of law from a populist attack.

Drawing on sources including years of participant observation providing unique and insider knowledge, the author analyzes the activities and outputs of CSOs and judges focusing on their interactions and cooperation. The author argues that CSOs play a significant role in the struggle for the rule of law and judicial independence. This Article demonstrates that CSOs' current engagement and input is not an extraordinary, ad hoc phenomenon, but rather one that arose from the previous interactions between the judiciary and civil society. The author argues that what we witness in Poland is an unprecedented phenomenon, both in the character of the relationship between judges and CSOs, and the scale and diversity of their cooperation. At the same time, the author claims that CSOs are underappreciated, including by academia, their work is taken for granted, and their role in the legal complex can be seen as a partly lost opportunity. If noticed, appreciated, and supported CSOs activities and their role could be more meaningful.
\end{abstract}

Keywords: Judiciary; Civil Society Organizations (CSOs); judicial resistance; legal complex; civic engagement; role of the judiciary

\section{A. Introduction}

Society is being destroyed like this: First, the rule of law must be broken by force. This must be done openly and publicly, in front of the entire society. [...] The experience of one's own powerlessness in the face of violence destroys the energy of the individual, but the experience

Łukasz Bojarski is a Doctoral Research Fellow at the Department of Private Law, Law Faculty, University of Oslo. Łukasz takes part in the research project Judges under Stress (JuS) - the Breaking Point of Judicial Institutions.

I thank the following people for their valuable comments on the draft version of the Article: Maria Ejchart-Dubois, Hans Peter Graver, Jarosław Gwizdak, Ewa Łętowska, Danuta Przywara, Grzegorz Wiaderek, Nina Witoszek, Mirosław Wyrzykowski. My special thanks for their extraordinary contribution go to Leah Wortham, Magda KrzyżanowskaMierzewska and Marek Antoni Nowicki. I also thank other numerous judges, lawyers, and representatives of the CSOs who shared with me their personal experiences.

(C) The Author(s) 2021. Published by Cambridge University Press on behalf of the German Law Journal. This is an Open Access article, distributed under the terms of the Creative Commons Attribution licence (https://creativecommons.org/licenses/by/4.0/), which permits unrestricted re-use, distribution, and reproduction in any medium, provided the original work is properly cited. 
of the public impotence of the law hurts more severely: it undermines faith in the reality of society. ${ }^{1}$

\section{"THIS IS OUR COURT"}

(2017) An inscription displayed on the Supreme Court's wall. ${ }^{2}$

Thanks to the courage and determination of judges, prosecutors, lawyers and citizens, the justice system has not yet collapsed. It is up to us to ensure that the spirit of justice survives and that the rule of law is rebuilt. ${ }^{3}$

Since the October 2015 parliamentary elections in Poland, the government coalition led by the Law and Justice party (Prawo i Sprawiedliwość, PiS) claimed to "reform" the judiciary. Almost unanimously, international institutions such as the European Union, Council of Europe, and United Nations, as well as academia, termed these as attacks on the courts, judicial independence, and democracy, and assessed them as rule of law backsliding, constitutional breakdown, and constitutional coup d'état. This process is being reported and analyzed on an ongoing basis. ${ }^{4}$

In short, the government targeted first the Constitutional Tribunal (CT), then the National Council of the Judiciary (NCJ), the Supreme Court (SC), and the ordinary courts. In response to subsequent moves of the government, many judges undertook various activities to defend the independence of the judiciary and judges and, more broadly, to defend the attacked institutions of liberal democracy. The active reaction of a big part of Polish judges is a special one and worth analyzing against the background of the world experience with its examples of rather individual and not strategic and systemic judicial resistance. ${ }^{5}$

The Polish Constitutional Tribunal was paralyzed and then 'packed' and used as a tool of the governing majority, ${ }^{6}$ the NCJ subjected to politicians, the Supreme Court attacked and packed, and ordinary courts influenced by appointments of new presidents by the Minister of Justice. Polish judges, as of September 2021, are still under constant pressure, targeted by the executive and by the ruling parties as a group — through organized hate campaigns and 'muzzle laws' - and as individuals to create a chilling effect and punish those who do not wish to follow the whims of the executive. Nevertheless, after more than five years, a substantial group of judges manages on a large scale to take various actions to defend judicial independence. ${ }^{7}$

\footnotetext{
${ }^{1}$ Bohdan Cywiński, Kiedy przestajesz się bać, Tygodnik Solidarność, Apr. 10, 1981, at 4 (translated by author).

2"To jest nasz sąd," an inscription displayed on the wall of the Supreme Court by Akcja Demokracja during the "Chain of Light" protest event, July 2017.

${ }^{3}$ Wolne SĄDY, 2000 DAYs OF LAWlESSnEss (Sylwia Gregorczyk-Abram, Paulina Kieszkowska-Knapik, Michał Wawrykiewicz, Maria Ejchart-Dubois \& Krzysztof Michałowski eds., 2021), https://wolnesady.org/files/2000_days_of_ Lawlessness_FreeCourts_Report.pdf.

${ }^{4}$ See Wojciech Sadurski, Poland's Constitutional Breakdown (2019); Dariusz Mazur, Laurent Pech \& Patryk Wachowiec, 1825 Days Later: The End of the Rule of Law in Poland, part I and II, VerfBlog (Jan. 28, 2021), https:// verfassungsblog.de/1825-days-later-the-end-of-the-rule-of-law-in-poland-part-ii/. See also academics' numerous blog entries or group statements/open letters, for example the VERFASSUNGSBLOG published in 2015-20 around 270 posts devoted to rule of law crisis in Poland (information from Maximilian Steinbeis, Chief Editor, Jan. 18, 2021). For numerous documents, statements, opinions of both international and Polish actors, see civic initiative: https://ruleoflaw.pl/ and the crisis calendar: WOLNE SĄDY, supra note 3.

${ }^{5}$ See, e.g., Hans Petter Graver, Judges Against Justice: On Judges When the Rule of Law Is under Attack (Springer, 2015); Hans Petter Graver, Jussens Helter (2020) (mentioning examples of judicial resistance).

${ }^{6}$ See Wojciech Sadurski, Polish Constitutional Tribunal Under PiS: From an Activist Court, to a Paralysed Tribunal, to a Governmental Enabler, 11 Hague J. Rule L. 63 (2019).

${ }^{7}$ There is no reliable data showing what part of the 10,000-member group of judges supports judicial resistance. Some dozen judges are visible and symbolic for the protest, some hundreds of judges are regularly active, but some thousands of judges support different actions. For instance, over 4,000 judges signed a letter calling on the government and the President of the Supreme Court to implement the rulings of the Court of Justice of the European Union. See Mariusz Jałoszewski, Wielki
} 
The interaction and cooperation of resisting judges with other actors and their support for judicial activities is worthy of study. The key stakeholders supporting or cooperating with resisting judges are international organizations and institutions, legal academia, the legal professions, and civil society organizations (CSOs). Existing writings on Poland do not analyze the legal complex understood widely and incorporating not only 'bench and bar' but also other legal professions, the legal academy, and civil society. ${ }^{8}$ The aim of this Article is to take a closer look at CSOs' activities vis a vis courts and judges. ${ }^{9}$ My argument is three-fold.

First, I show that CSOs can potentially play, and sometimes do play, an essential role in the struggle for the rule of law and judicial independence. The role of their support for the judiciary, their struggle for independent courts, and their defense of liberal values under attack is significant even if CSOs seem underrated. The present situation in Poland is a starting point. But how did it happen that Polish CSOs are currently an essential element of the legal complex, and their role and interaction/cooperation with judges is significant? Is it an extraordinary phenomenon, born ad hoc only because of the gravity and immediacy of the situation? Or does it arise, as I argue, from the previous interactions between the judiciary and civil society? Accordingly, I also cover two previous historical periods.

Second, from the comparative perspective, I argue that what we are currently witnessing in Poland is a noteworthy phenomenon with no precedent, both concerning the character of the relationship between judges and CSOs and the striking scale and diversity of interaction and cooperation.

Third, I argue that the role of the CSOs in the legal complex might be partly seen as underappreciated and not fully acknowledged because other actors, including legal academia, do not treat it as a serious point of reference and overlook the importance of the phenomenon.

Some definitions are necessary to make sense of my arguments. Legal complex follows Halliday and Karpik's definition: “The legal complex denotes legal occupations which mobilize on a given issue at a given historical moment, usually through collective action that is enabled through discernible structures of ties." 10 This notion is beneficial to show and prove the significance of the CSOs' role. I do apply this concept but am also of the opinion that it could be more theoretically developed when it comes to the role of the CSOs, as stated in my final conclusions. ${ }^{11}$ One should also note that in Poland lawyers traditionally did not identify themselves with 'one legal profession' but with different legal occupations or professions like judges, prosecutors, notaries, or attorneys-at-law grouped in two professions: advocates and legal advisors. ${ }^{12}$ All these occupations have separate career paths and the transition between them, however possible, is more difficult and less frequent than in common law countries. Furthermore, legal scholars and lawyers working for CSOs are not treated as members of the legal profession unless, as is often the case, they are also members of one of the aforementioned legal occupations.

The terms Civil Society Organization (CSO) and third sector organization appear for what most authors call Non-Governmental Organizations (NGOs). ${ }^{13}$ The name 'CSO' emphasizes civil

historyczny apel polskich sędziów w obronie prawa UE. Ostateczna lista 4219 nazwisk, OKO.PREss (July 31, 2021), https://oko. press/wielki-historyczny-apel-polskich-sedziow-w-obronie-prawa-ue-ostateczna-lista-4219-nazwisk/.

${ }^{8}$ See The Legal Complex and Struggles for Political Liberalism, in Fighting FOR POLITICAL FREEDOM: COMPARATIVE Studies of the Legal Complex and Political Liberalism, (Terence C. Halliday, Lucien Karpik \& Malcolm M. Freely eds., 2007).

${ }^{9}$ In the empirical research, the author relies in part on participatory observation. In 1989-2015, I worked for CSOs focusing on judiciary - mainly the Helsinki Foundation for Human Rights in Poland — and state bodies—in 2010-2015 as a member of the National Council of the Judiciary. In 2015-2020, I was involved in different activities aiming at defending judicial independence as president of the legal think tank INPRIS and as co-founder, in June 2018, of the Justice Defense Committee KOS.

${ }^{10}$ Lucien Karpik \& Terence C. Halliday, The Legal Complex, 7 AnN. Rev. L. \& Soc. SCI. 217 (2011).

${ }^{11}$ This is an interesting subject for a separate article, in which one can use the examples and arguments presented in this Article.

${ }^{12}$ Legal advisors (radcowie prawni) was a legal occupation created by communists in opposition to 'bourgeois advocates, and in order to counsel and represent mainly public enterprises and entities.

${ }^{13}$ Other possible names: organizations of non-profit; voluntary sector; independent sector. 
society and citizens as subjects, while NGO defines organization just in opposition to governmental structures. For the purpose of this Article, I am defining CSOs as groups of citizens who associate for a chosen purpose in the form of associations, foundations, or less formal initiatives. I do not include in this group political parties, unions of workers or employers, churches, or religious groups. ${ }^{14}$ Even within such limited scope, I am not interested in all CSOs. I refer in the Article to the traditions of state-building as a civil society, meaning a liberal democracy respecting human rights. Both - in the past and present - other entities are also active-for example, by CSOs expressing nationalistic-ultra religious-populistic ideas. However, I deliberately focus on CSOs that recognize a current threat to the rule of law, and not on the significantly fewer organizations that support the government and its 'reform' of the justice system. ${ }^{15}$ Among the CSOs, I also include judges' associations, as these are not official organizations, but private voluntary associations.

The use of interaction, communication, and cooperation, underlines the differing relationships between the courts/judges and CSOs. Because judges are supposed to be independent and impartial, their cooperation with other subjects is limited, while communication or interaction happens more often.

Finally, by judicial resistance I mean activities of judges undertaken individually or collectively, in court or out of court, against measures aiming at limiting judicial independence or, more comprehensively, backsliding the rule of law. Measures that we can characterize as breaching the rule of law standards accepted by the state and enshrined in the constitution, national and international law. ${ }^{16}$

This Article is organized as follows. Part B takes a brief look at the final period of a communist state (1970s-1980s). Part C analyzes the era of building democracy and the rule of law (1989-2015). Part D analyzes what CSOs have been doing for and with the judiciary over 2015-2020. Parts B, C, and D cover three different historical periods, but they follow the same structure with a division into three subsections devoted to (I) the background, (II) interaction of CSOs with courts and judges, and (III) conclusions. Finally, Part E concludes with an assessment of the possible role played by CSOs vis a vis judges and courts in the broader context of legal complex and judicial resistance.

\section{B. People's Republic: Time of Oppression (1976-1989) \\ 1. Under Control of the Party: Background}

During the so-called socialist era, both the judicial system and the landscape of the third sector were controlled by the state. The socialist system was characterized by essentially one communist party-based domination of everything that was public. Although Poland was declaratively a democracy and a state under the rule of law, each of these terms was preceded with the word "people's" or "socialist." A joke from the epoque illustrates this well. When asked "what is the difference between the democracy/the rule of law and the socialist democracy/the rule of law?" the answer was "similar to what differs a chair from an electric chair."

The judiciary in communist Poland was under the control of the ruling party. Although in the 1970s and 80s, judges and courts were different from Stalinist courts, being part of the state terror machinery in the $1940-50 \mathrm{~s},{ }^{17}$ the communist constitution of 1952 left no illusions. While it

\footnotetext{
${ }^{14}$ But see Fighting for Political Freedom: Comparative Studies of the Legal Complex and Political Liberalism (Terence C. Halliday, Lucien Karpik \& Malcolm M. Freely eds., 2007) (presenting a different approach on the scope of 'civil society' as an element of the legal complex).

${ }^{15}$ One such organization is a very active - including on the international scene-and influential legal think tank, The Ordo Iuris Institute for Legal Culture, founded in 2013. See ORDOIURIS, https://en.ordoiuris.pl/ (last visited Sept. 1, 2021).

${ }^{16}$ See also Hans Petter Graver, Why Adolf Hitler Spared the Judges: Judicial Opposition Against the Nazi State, 19 GERMAN L.J. 845, 864 (2018) (discussing other possible terms in the section 'A Typology of Judicial Opposition').

${ }^{17}$ See ANDRZej RZEPliński, Die Justiz IN DER Volksrepublik Polen (Maria Veronika Janssen trans., Andrzej Kałuża ed., 1996).
} 
declared that judges were to be independent and trials public, ${ }^{18}$ it did not guarantee the right to a court or fair trial and formulated the role of courts as: "[C]ustodians of the social and political system of the Polish People's Republic" who "shall safeguard the people's rule of law, social property and the rights of citizens" as well as "shall punish offenders." 19

Civil Society, understood as a form of freely grouping citizens to pursue a common goal or interest, was very limited. Few bottom-up private third sector organizations focusing on law or dealing with the judiciary existed. The landscape of "imperfect civil society" consisted of "pseudo-civil society official associations" and "illegal civil society."20

Significant developments took place in the 1980s. The nationwide strikes in August 1980 - something previously almost unheard of in 'peoples' democracies'-led to the signing of an agreement with the government and the creation of Solidarność, the first independent trade union in the Soviet sphere of influence. ${ }^{21}$ The following, fifteen month long, 'Solidarity era' was a time of citizens' enthusiasm to change the reality around them, far beyond the classical role of trade unions. About ten out of thirty-five million citizens signed up for Solidarność, which naturally dominated the civil society scene and absorbed most of the persons previously active in any sphere of social or quasi-political activity. ${ }^{22}$ Solidarność also found its way to judges. Creating the Judicial branch of Solidarność was not easy, yet according to various estimates, about one out of three thousand judges were union members. ${ }^{23}$ This demonstrates both the hopes placed in this social movement and the courage of the judges who became members of an organization that opposes authoritarian power.

The 'Solidarity era' ended with the imposition of martial law on December 13, 1981 and the imprisonment as so-called 'internees' of ten thousand activists without any proper legal basis. ${ }^{24}$ As Kubik notes: "After the delegalisation of Solidarity in 1981, independent social activity moved underground. Illegal civil society, which formed almost overnight, was diversified but also strongly unified by a common symbolic umbrella in the myth of Solidarity." 25 The 'era of martial law' lasted until 1988-89, although the 'martial law' itself technically ended in July 1983.

\section{Underground Activists and Duty Judges}

Can we speak of any interaction, or maybe cooperation, of civil society with courts and judges in the difficult circumstances of people's democracy outlined above? The most relevant civil society activities in the 1970s were those of two 'illegal' groups: (a) The Workers' Defense Committee (Komitet Obrony Robotników, KOR) created in $1976^{26}$ and (b) the Movement for Defense of Human and Civic Rights (Ruch Obrony Praw Człowieka i Obywatela, ROPCiO).

\footnotetext{
${ }^{18}$ Constitution of the Polish People's Republic July 22, 1952; Dziennik Ustaw, No. 7, item 36, art. 62 ("Judges shall be independent and subject only to the law"); Dziennik Ustaw, No. 7, item 36, art. 63.1 ("Cases in all Courts of the Polish People's Republic shall be heard in public ....").

${ }^{19}$ Constitution of the Polish PeOple's Republic July 22, 1952, art. 58.

${ }^{20}$ There was for instance Zrzeszenie Prawników Polskich (Union of Polish Lawyers) founded in 1945, but it was not a grassroots organization, but rather 'pseudo civil society' official organization embedded in the system. In order to establish an independent CSO one was left with the 'illegal' alternatives. See Jan Kubik, Between the State and Networks of 'Cousins': The Role of Civil Society and Non-civil Associations in the Democratization of Poland, in CIVIL Society Before Democracy: Lessons from Nineteenth-Century Europe 181 (Nancy Bermeo \& Philip Nord eds., 2000).

${ }^{21}$ See What is the NSZZ "S," SolidARNOŚć, https://www.solidarnosc.org.pl/en/.

${ }^{22}$ They were however some exceptions. For instance, in July 1981, the President of Warsaw entered the "Patronat" Association for Assistance to Imprisoned Persons and their Families into the register of associations. See Rejestracja „Patronatu”, 22 Tygodnik Solidarność, Aug. 28, 1981, at 15.

${ }^{23}$ See Maria Stanowska \& Adam StrZembosz, SędZIOWie WarsZawscy w CZasie Próby 1981-1988 (Instytut Pamięci Narodowej, 2005), at 56-66.

${ }^{24}$ See Patryk Pleskot, Prawo i bezprawie: Komitet Helsiński w Polsce 1982-1990 (2017), at 27.

${ }^{25}$ Kubik, supra note 20 , at 278 .

${ }^{26}$ Reorganized in 1977 into the Committee for Social Self-defense KOR [Komitet Samoobrony Społecznej KOR].
} 
$\mathrm{KOR}$ and $\mathrm{ROPCiO}$ relied on rights/liberties - like freedom of association - that technically existed under the 1952 Constitution, but were treated by the political powers merely as window dressing and very severely restricted in practice. They argued that they do nothing but exercise their citizen's rights guaranteed by the then legal order. Additional impetus to their creation had been provided by the 'Helsinki process' and the 1975 Helsinki Accords. ${ }^{27}$

The Workers' Defense Committee KOR was a civil society group ${ }^{28}$ founded initially to provide aid to demonstrators after the June 1976 protests about the impending rise in the cost of basic commodities in Radom and Ursus - primarily those arrested and facing criminal trials for their participation in the street protests. ${ }^{29} \mathrm{KOR}$ activities included organizing and financing legal representation for political detainees, financial support for their families, and cooperation with advocates and doctors-medical aid and medical reports were presented as evidence of police brutality at trials. ${ }^{30}$

KOR also attempted to observe those trials. Representatives of KOR tried to enter the courtrooms. During such initial attempts, groups of observers were arrested in the court building, brought to a police station, and subjected to informal interrogation attempts, body searches, and sometimes beatings. However, after some time, the campaign for the right to observe trials was won. Still, occasionally, observers were detained by police or attacked by 'unknown perpetrators,' damaging observers' cars or beating them, including in the court building and with no reaction from police. ${ }^{31}$

What started with informal teams supporting workers in Ursus and Radom developed into a social network active for over four years. KOR began with a handful of heroes in a rather passive society - a risk of oppression was very high—fourteen signatories and around thirty official members. Over the years the network grew to hundreds of collaborating associates. It established the KOR Intervention Bureau helping parties in labor law cases-mostly employees dismissed for their participation in protests - and giving legal advice in conflicts with the administrative apparatus and police. KOR also focused on monitoring and reporting by preparing The Documents of Lawlessness, well-documented cases of political killings and severe beatings, ${ }^{32}$ and by establishing the Helsinki Commission, which acted within KOR from January to September of 1980. It prepared a report on the implementation of the Helsinki Final Act $^{33}$ by Polish authorities, covering four years of KOR activities. ${ }^{34}$ The KOR efforts had been in part successful. ${ }^{35}$ It was also the first initiative with a more systemic approach to the work of courts.

The Movement for Defense of Human and Civic Rights (ROPCiO) was a civil society group ${ }^{36}$ that went public on March 25, 1977, by publishing the declaration signed by eighteen people. The declared goals of the Movement were to protect human and civil rights and to enforce-with recourse to legal actions-compliance of the communist government with ratified international

\footnotetext{
${ }^{27}$ See Helsinki Final Act, Conference on Security and Co-Operation in Europe (1975).

${ }^{28}$ See JAN JÓzef LiPSKi, KOR: A History of the Workers' Defense Committee In Poland, 1976-1981 (1985); Jan Skórzyński, KOR and Its Model of Resistance: Study of Dissent and Opposition in the Communist Poland, 125 Kwartalnik Historyczny 87 (2018); Kacper Szulecki, Dissidents in Communist Central Europe: Human Rights and the Emergence of New Transnational Actors (2019); Nina Witoszek, The Origins OF AntiAUTHORITARIANISM (2019).

${ }^{29}$ Prices were fixed and controlled by the government. A group of activists began organizing support for workers that, after a couple of months, led to the founding of KOR. See LIPSKI, supra note 28, at 30.

${ }^{30} I d$. at $79-83$.

${ }^{31}$ Id. at $84-87$.

${ }^{32} I d$. at $218-26$.

${ }^{33}$ Helsinki Final Act, CONFerence on SeCurity AND Co-Operation in Europe, (1975), https://www.osce.org/files/f/ documents/5/c/39501.pdf.

${ }^{34}$ See Prologue to Gdansk: A Report on Human Rights by the Polish Helsinki Watch Committee (1980).

${ }^{35}$ As a result of the workers' protests the government withdrew from price increases, but also in the spring of 1977 declared the amnesty for jailed workers.

${ }^{36}$ See GrZegorz WaligóRa, Ruch Obrony Praw CzŁowieka i Obywatela 1977-1981 (2006); Jan Skórzyński, “Apel do społeczeństwa polskiego" i geneza ROPCiO, 2 PAMIĘć I SPRAWIEDliwoŚć 317 (2008).
} 
human rights treaties. Poland had ratified the UN International Covenants only a few days earlier. $^{37}$

ROPCiO operated in three main ways: (a) Publishing appeals, declarations, and open letters addressed to the authorities, like a Declaration on Freedom of Speech or Open Letter on Freedom of Conscience and Religion; ${ }^{38}$ (b) organizing help and counseling for people persecuted by the regime in local consultation points in private apartments of various towns; (c) informational and educational activities, underground publications, like handbooks on conduct to be followed during detention and interrogation by Militia or Security Service. ${ }^{39}$

During Solidarność time-mainly in 1981—-several exciting processes took place. ${ }^{40}$ Two trade unions with relevance to judges were created: The judicial branch of Solidarność and-in opposition to it-an official Union of Justice Workers. ${ }^{41}$ Judicial Solidarność held an open and lively debate on the independence of courts and judges. Numerous attempts were made to bring about changes, including by way of work on drafts of bills reforming the judicial system and taking it out of the communist party control.

In April 1981, "Solidarność Weekly" ${ }^{2}$ began publication, a forum for a nationwide discussion about reform of the state-though still subject to censorship. It published several articles devoted to the rule of law and judicial reform. Judges themselves also spoke out. In their programmatic theses-Directions of the Union ... - and positions for negotiations with the government, representatives of Solidarność stressed the need for judicial reform, the importance of the independence of the judiciary, and judicial self-government. ${ }^{43}$ Supreme Court judge Zofia Wasilkowska formulated directions for reform of the Supreme Court. ${ }^{44}$ Members of Solidarność were urged to take advantage of the then-existing provisions on the possibility of participation in court proceedings by a so-called 'social representative'. ${ }^{45}$

Judge Adam Strzembosz underlined in the interview the active role of the Solidarność union in the courts—over 9000 members including 1000 judges: "We are currently witnessing a huge surge of activity on the part of the court staff ... draft laws and amendments are created spontaneously and voluntarily, we conduct lectures, presentations, we discuss." ${ }^{\prime 6}$ Strzembosz was one of the most active supporters of judicial self-governance. ${ }^{47}$

Dozens of judges protested misinformation by signing Lawyers' Statement, an objection against the state media presenting the country situation as threatening security because of allegedly increased crimes or hooliganism during the Solidarność era. This Statement was also published in the "Solidarność Weekly." This was proof of their courage. ${ }^{48}$

\footnotetext{
${ }^{37}$ International Covenant on Civil and Political Rights (ICCPR) and International Covenant on Economic, Social and Cultural Rights (ICESCR), New York, Dec. 16, 1966, both entered into force in 1976.

${ }^{38}$ Deklaracja o wolności słowa (Declaration on freedom of speech); List otwarty w sprawie wolności sumienia i wyznania (Open letter on freedom of conscience and religion).

${ }^{39}$ WALIGÓRA, supra note 36.

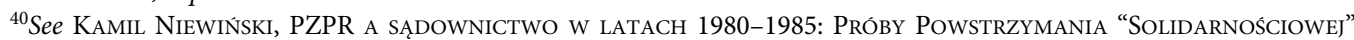
REWOLUCJI (2016).

${ }^{41}$ See STANOWSKa \& STRZEMBOSZ, supra note 23, at 42-66.

${ }^{42}$ From April until December 1981, thirty-seven numbers of TyGODNIK SOLIDARNOŚć were published.

${ }^{43}$ See Kierunki działania związku w obecnej sytuacji kraju. Część 4.1, Praworządność, 3 TygODNIK Solidarność, Apr. 17, 1981, at 6; Praworządność. Stanowisko KPP do rokowań z rządem, 6 Tygodnik Solidarność, May 8, 1981 , at 7.

${ }^{44}$ See Zofia Wasilkowska, Sąd Najwyższy, 7 TYGODNIK SolidARnOŚć, May 15, 1981, at 13.

${ }^{45}$ A person supporting on behalf of the organization a 'social interest' and/or an individual party to the case. See Lech Falandysz, Przedstawiciel społeczny, 9 TYGoDNIK SOLIDARNość, May 29, 1981, at 11.

${ }^{46}$ See interview with Adam Strzembosz, „Solidarność” pracowników wymiaru sprawiedliwości, 10 TYGODNIK SOLIDARNOŚć, June 5, 1981, at 10 .

${ }^{47}$ See Adam Strzembosz, O samorządne sądownictwo w samorządnej Rzeczypospolitej, 33 TYGODNIK SOLIDARNOŚć, Nov. 13, 1981, at 13 .

${ }^{48}$ See Oświadczenie prawników, 9 TYGODNIK SOLIDARność, May 29, 1981, at 1; Oświadczenie prawników, 11 TYGODNIK Solidarność, June 12, 1981, at 5; Oświadczenie prawników, 13 TYgodnik Solidarność, June 26, 1981, at 3.
} 
At the same time, very critical voices of citizens directed at the judiciary were heard, calling for reform and vetting procedures in the future. ${ }^{49}$ Some judges reacted to the accusations - at times quite nervously — by defending themselves and claiming that many of them have maintained their dignity and independence and that the denunciations were an unfounded generalization. ${ }^{50}$ Other judges agreed with the critics. ${ }^{51}$

Six judges from Gdańsk admitted in their written statements that they had been subjected to unlawful pressure from the provincial court president instructing them on how to decide specific cases. ${ }^{52}$ They openly informed in which cases they had succumbed to pressure and when they had not. These confessions resulted in the actions of Solidarnośc, which led to the dismissal of the court president. ${ }^{53}$

During the First Congress of Solidarność in September/October 1981, the union's delegates passed a "Resolution on the Independence of the Judiciary." ${ }^{4}$ They expressed their conviction that it was impossible to reform the state without guaranteeing an independent judiciary. The Congress asked "all workplace organizations to widely disseminate those theses of the Union's program which concern the guarantee of judicial independence ..." as well as obliged the union's leadership to "particular activity in negotiating" the guarantee of independence with the authorities. ${ }^{55}$ The Congress also asked all union members to support these activities, "including protest action" if necessary. ${ }^{56}$ This demonstrates that the judicial agenda was an important part of the activities and claims of the protest movement, and not only a fringe preoccupying those with special interest.

During the Solidarność era, the communities of advocates and legal advisers were trying to become professions independent from the state. Advocates and legal advisers worked on relevant draft laws ${ }^{57}$ and met during the groundbreaking National Congress that had adopted relevant resolutions. ${ }^{58}$ Judges, lawyers, and legal scholars cooperated in the Center for Civic Legislative Initiatives of Solidarność and its Social Legislative Council, created in January 1981 in Krakow and headed by the rector of the Jagiellonian University. From 1981 to 1992, the Center developed several dozen draft bills, involving around 100 experts and 200 collaborators. ${ }^{59}$ This included essential drafts related to the judiciary.

In December 1981, after the imposition of martial state law, the most important were the activities of the Polish Helsinki Committee (Komitet Helsiński, KH) created in $1982 .{ }^{60}$ The Committee revealed its existence in January 1983 with the publication of its first report and operated underground until 1988 when its members disclosed their names. The first report (1000 pages), "Human and Civil Rights in the Polish People's Republic during the Martial Law Period Dec. 13, 1981-Dec. 31,1982 ," 61 was clandestinely taken out of the country "to the west" and published there. Authors declared in the report that:

\footnotetext{
${ }^{49}$ See, e.g., Janusz Ślęzak, Dlaczego polskie sądownictwo powinno być samorządne?, Jolanta Strzelecka, Sędziowie?, 11 TYGODNIK SOLIDARNOŚć, June 12, 1981, at 12-13.

${ }^{50}$ See Protest; Jacek Ambroziak, Dyspozycyjni sędziowie; Joanna Strzelecka, List sędziów poznańskich, 20 TYGODNIK Solidarność, Aug. 14, 1981, at 13.

${ }^{51}$ See Krzysztof Kauba, "Solidarność” w resorcie sprawiedliwości, 24 TYGODNIK SOLIDARNOŚć, Sept. 11, 1981, at 14; Janusz Rudnicki, Jacy sq sędziowie, 25 TygODNIK SOLIDARNOŚć, Sept. 18, 1981, at 13.

${ }^{52}$ See Wanda Falkowska, Votum nieufności, 33 Tygodnik Solidarność, Nov. 13, 1981, at 12.

${ }^{53} I d$. at 12 .

${ }^{54}$ See Uchwała w sprawie niezawisłości sądownictwa, 30 TYGODNIK SOLIDARNOŚć, Oct. 23, 1981, at 10 (translated by author).

${ }^{55} I d$. at 10.

${ }^{56} I d$. at 10 .

${ }^{57}$ Paradoxically both Acts, on the Bar and on the Legal Advisors, prepared during Solidarność era, were passed by the Parliament during the martial law state in 1982.

${ }^{58}$ Ogólnopolski Zjazd Adwokatury [National Congress of the Bar], Jan. 3-4, 1981, Poznań.

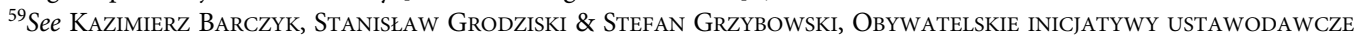
SOLIDARNOŚCI 1980-1990 (Wydawnictwo Sejmowe, 2001).

${ }^{60}$ See Patryk Pleskot, Prawo i bezprawie : Komitet Helsiński w Polsce 1982-1990 (2017).

${ }^{61}$ Prawa Człowieka i Obywatela w PRL w okresie stanu wojennego Dec. 13, 1981-Dec. 13, 1982.
} 
The aim of the Committee is to collect, prepare and publish materials concerning violations of human rights in the People's Republic of Poland. The Committee does not represent any political line .... We only want to participate in the fight against lawlessness by broadly informing about its various manifestations. ${ }^{62}$

This first report, and five more prepared in subsequent years, consisted of both analysis of the laws and their compliance with Poland's international obligations - as they stood at that time-and detailed documentation of cases of individual human rights violations.

In addition to the reports, the Polish Helsinki Committee has been constantly involved in discussions about the judiciary. Judicial issues were present in the clandestine periodic 'The Rule of Law' (Praworządność) ${ }^{63}$ and in the column 'The Rule of Law' (Praworzadność) published systematically for five years in the underground magazine KOS. ${ }^{64}$ In 1985, at Solidarność request, the most important theses were formulated as part of the Solidarity report: 'Poland - Five Years after August'. ${ }^{65}$ And in October 1988, the Committee delivered a position on the judiciaryamong other issues - in the document 'Civil rights - The Law and the Rule of Law', which later became an important document in the context of the 'Round Table Talks'. It emphasized the role of judicial independence as a basic condition for the effective protection of rights and freedoms. ${ }^{66}$

With the judicial issues the Committee tried also to get through to the official press, which was effectively prevented by censorship. Marek Antoni Nowicki recalls:

In order to circumvent the impossibility of criticizing the judiciary in the People's Republic in the official press, I decided to describe the ongoing judicial reforms in the USSR (the era of perestroika). ${ }^{67}$ The basis was the Soviet press of that period, especially Ogoniok (Russian Огонёк) which published a lot about it. For us it was fascinating reading, we had never come across such a discussion in our lives, and that it was possible to write such things in newspapers. I spent many months in a Koszykowa library, poring over those Ogonioks and others like them. It read like the underground press.

Information on the Helsinki Committee in 1988 also could not be published. The brave newspapers only mentioned Article 6 of the Censorship Act, on the basis of which publication was refused. ${ }^{68}$

The Helsinki Committee built a network of collaborators and experts, often using already existing structures-for example, the underground Solidarność and the network of aid committees established in dioceses and parishes. The information was collected from underground activists but also cooperating advocates, prosecutors, and judges. ${ }^{69}$

The actual modus operandi and the identities of participants in this work are partly shrouded in mystery. We have only incomplete information on cooperation of judges with CSOs in the 1980s. The Helsinki Committee members in their reports referred to cooperation with judges but did not provide any details. ${ }^{70}$ Because the Committee acted underground, this cooperation has no adequate documentation. Marek Antoni Nowicki was in contact with lawyers-mainly

\footnotetext{
${ }^{62}$ See Pleskot, supra note 60, at 51.

${ }^{63}$ Interview with Marek Antoni Nowicki, Co-founder, Polish Helsinki Committee (July 2021), See also Praworządność, No. 1-21, HeLsinKi COMMitTEE, https://www.hfhr.pl/komitet-2/biuletyn/.

${ }^{64}$ Interview with Marek Antoni Nowicki, Co-founder, Polish Helsinki Committee (July 2021).

${ }^{65}$ See POLSKA 5 LAT PO SIERPNiU. RAPORT (Poland Five YeArs AfTER August. Report), ANEKS, 1986.

${ }^{66}$ See Prawa Obywatelskie - prawo i praworządność, Biuletyn nr 1, KOMITET HelsiŃsKi w POLSCE, 1988 at 33-43, hfhr.pl/ komitet-2/biuletyn/.

${ }^{67}$ See Marek Nowicki, Pierestrojka i Temida, Tygodnik Powszechny, February 14, 1988, at 3.

${ }^{68}$ Interview with Marek Antoni Nowicki, Co-founder, Polish Helsinki Committee (July 2021).

${ }^{69}$ See Pleskot, supra note 60, at 26.

${ }^{70} \mathrm{Id}$. at $26-28,99$.
} 
attorneys and prosecutors, but also judges — on behalf of the Committee. He claims that the Polish Helsinki Committee cooperated with several dozen judges who provided various information, but personally knew only a few of them due to the underground rules. ${ }^{71}$

Nowicki, a former prosecutor himself, mentions as examples the fellow prosecutors taking files out of the offices, under the mantle, with a view to providing information for the purposes of the reports, or the name of the retired Supreme Court judge who provided her apartment for some secret meetings of the Helsinki Committee. ${ }^{72}$ However, there are probably more stories and examples to be found. ${ }^{73}$

The activities of Stanisław Dąbrowski provide one example of judges involved in, or supporting activities of, the anti-communist underground. At his 2014 funeral ceremony-he passed away being the First President of the Supreme Court - those gathered learned that throughout the martial law period, when he was already a judge, Dąbrowski made his apartment available to a Solidarity activist hiding from the secret police. He also transported-on a sled-and held in his flat, an illegal duplicator of the underground organization. Although he was a prominent public figure after 1989, a member of Parliament, Chairman of the NCJ, and President of the Supreme Court, this 'underground' part of his biography was not publicly known until after his death. ${ }^{74}$

\section{The Pull of Heritage}

Despite the lack of real freedom, democracy, and the rule of law, the last fifteen years of the 'people's democracy' was also the time when social movements initiated for the first time a more strategic approach to the 'legal actions.' The KOR, the ROPCiO, and the Helsinki Committee, emphasized the protection of human rights they should enjoy vis-à-vis the communist state authorities and the state's obligation of compliance with its international obligations.

For the first time, it was possible to refer to the documents signed by the communist regime: The 1975 Helsinki Final Act-with its section VII 'Respect for Human Rights and Fundamental Freedoms, Including the Freedom of Thought, Conscience, Religion or Belief - and to the UN International Covenants-with the right to an independent court, Article 14 ICCPR. Oddly enough, a law on the ratification of the Covenants was published in the Journal of Laws with the information that they constituted an annex to the law, but this was not published. The first publication, unofficial, did not take place until five years later, during the Solidarity period. Thus, citizens could not get acquainted with the rights guaranteed by these documents. As Nowicki put it, "International human rights documents were like us, in the underground." 75

Today, we probably would describe these organizations as CSOs or even public interest law groups. However, their activities in interaction with the courts were limited-and in the 1980s, clandestine, hence kept in secret. In the 1970s, they focused on organizing legal representation in cooperation with a group of advocates who acted in political criminal trials of persons charged with various offences; on trial observation/documentation and providing support to the victims of the regime; and on informing the public about court cases conducted as acts of political oppression. In the 1980s, there was less trial observation but more involvement of actors like 'officers of the court' - mainly advocates - who provided detailed reports on particular cases investigated by the then "militia" (the police) and tried by the prosecution and the courts.

\footnotetext{
${ }^{71}$ Interview with Marek Antoni Nowicki, Co-founder, Polish Helsinki Committee (Dec. 2020).

${ }^{72}$ See Pleskot, supra note 60, at 27-28.

${ }^{73}$ This could be an interesting topic for a separate article.

${ }^{74}$ Author learned about it during a memorial service. See also ADWOKATURA POLSKA, Ostatnie pożegnanie Stanisława Dąbrowskiego, https://www.adwokatura.pl/ogolnoprawne/ostatnie-pozegnanie-stanislawa-dabrowskiego/ (Jan. 21, 2014).

${ }^{75}$ Interview with Marek Antoni Nowicki, Co-founder, Polish Helsinki Committee (July 2021). Nowicki recalls that still in 1987, Tygodnik Powszechny wanted to publish his article about freedom of forming and joining trade unions, quoting Article 22 of the Covenant. However, the article was removed in its entirety by the censors.
} 
Judges in the People's Republic during the period under consideration were treated by citizens with distrust, especially those adjudicating in political trials. ${ }^{76}$ It is difficult to talk about any open cooperation of citizens with judges as a group. It was more about an interaction between the general public and courts that took place without the intention on the part of the judges. The following story from Radom in 1976 illustrates how such judges were sometimes pushed against their will into protecting court observers. ${ }^{77}$

'Unknown perpetrators' organized by the authorities physically attacked trial observers and advocates in the court building, screamed at and insulted them, and threw eggs at them. ${ }^{78}$ The court's police locked themselves in the office and did not respond to requests for assistance or knocks. One of the KOR advocates trying to get away opened the door to a random hearing room and entered in with those being attacked. The eggs followed, landing in front of the judge. Incidents like this finally tipped the scales. The court president postponed all hearings that day and phoned the police. 'Unknown perpetrators' disappeared. Two police officers appeared, although two hours later. For the next couple of months, observers could do their job more freely.

The planned and structured trial observation started in the second half of the 1970s, but trial observations incidentally happened before. Jacek Taylor, a well-known advocate in political trials, describes a case of people detained during student and street riots in Gdańsk in March 1968. Taylor received a secret tip from the head of the court secretariat that some employees and judges are summoned to report to work on Sunday-to deal with cases against so-called hooligans, dealt with an expedited procedure. ${ }^{79}$

Taylor visited some advocates and requested them to come to the court on Sunday in case defense is needed; he also asked a colleague to organize a group of students to observe hearings. When police surrounded the court building on Sunday at 7:00 a.m., observers were already inside the advocates' room. When five hours later the police started to bring arrested students and workers, advocates were already waiting to provide defense and students to observe hearings. ${ }^{80}$ It can obviously be a matter of speculation only, but according to Taylor, professional defense by advocates and pressure put on judges by the presence of the student observers at the courtrooms led to the acquittal of several people. This proves that the personal pressure of civil society on judges is occasionally possible.

From different accounts-no scientific data is available, no reliable research was done during communist times - it seems that, especially before the Solidarność era, no one expected judges to act fairly in political trials. There was a strong common opinion that such cases were not assigned to judges randomly or under any known procedural rules of case management. They were widely perceived rather as "duty judges," the ones that political power trusted. Nevertheless, there were also voices emphasizing that judges—excluding criminal judges tasked with political cases—were trustworthy. ${ }^{81}$

Many political trials, especially since 1976, thanks to the cooperation with advocates and work of observers, were also monitored and reported in numerous underground publications (samiz$d a t)^{82}$ and radio broadcasts from abroad. ${ }^{83} \mathrm{We}$ can only guess in what way this kind of publicity influenced the behavior of particular judges. However, both the defense in particular trials and speeches of advocates - sometimes also of the accused themselves-as well as articles and

\footnotetext{
${ }^{76}$ See Adam Strzembosz \& Alicja Seliga, "Sądownictwo wykonywało najbrutalniejsze zadania rządzacych" rozmowa z prof. Adamem Strzemboszem, Krajowa RADA SąDOWnictwa. KWARTAlniK (2016/4).

${ }^{77}$ See LIPSKI, supra note 28 , at $86-87$.

${ }^{78}$ Even though, due to crisis, eggs were unavailable in local shops, so they had to receive them via 'another channel'.

${ }^{79}$ See Jacek TAYlor \& AnNa Machcewicz, NAprawdę trZeba byŁo coś Zrobić (2018), at 34-38.

${ }^{80} I d$. at $34-38$.

${ }^{81}$ This is a general impression from reading of the entire timeline of TYGODNIK SOLIDARNOŚc weekly, April-December, 1981.

${ }^{82}$ The Polish 'second circuit' of publishing (samizdat) in 1970s-1980s included some thousands of periodicals. See DRUGI ObIEG W PRL NA TLE SAMIZDATU W PAŃSTWACH BLOKU SOWIECKIEGO PO 1956 ROKU (Przemysław Gasztold-Seń, Natalia Jarska \& Jan Olaszek eds., 2016).

${ }^{83}$ Including broadcast in the Polish language by Radio Free Europe (Germany), BBC (UK) and Voice of America (USA).
} 
discussions on different forums, especially in the Solidarność Weekly, ${ }^{84}$ were addressed to the judges, both individually and as a group.

Finally, a large group of judges — one/third—joined Solidarność, part of them engaged in works on future judicial reform, and established contacts with other social groups. New personal ties were thus created between judges as well as judges and representatives of other groups, which will subsequently turn out to be important. Adam Strzembosz argues that this also resulted, among other things, in the independent positions of a group of judges adjudicating during the martial law period. His survey covering the dark years of 1981-88 indicates "a remarkable variety of attitudes among judges, ranging from the truly heroic to the extremely opportunistic." 85 On the other hand, when the martial law authorities banned Solidarność, a group of judges lost their jobs as a retribution for their engagement-less than five percent of those who joined the judicial Solidarność. ${ }^{86}$

The Polish Helsinki Committee noted:

After December 13, 1981, the erosion of public trust in the judiciary, which had lasted for over 40 years, deepened dramatically. The removal of judges for political reasons, the blatant availability of some judges to the Security Service, the lowering of the professional level, caused losses in public opinion about the judiciary that were difficult to compensate for. ${ }^{87}$

The fifteen months of Solidarność inspired debates and communication between judges and the society. The CSO side was 'represented' by the most prominent social movement in Polish history, Solidarność. Citizens started to voice their expectations. They also drew the public's attention to certain trials, monitoring and describing those evaluated as unfair and politically motivated and those assessed as fair. Good examples are administrative complaints brought and won by the 'Solidarność Weekly' against the state censorship agency-before the newly created Supreme Administrative Court. ${ }^{88}$

The monitoring of one of the most famous trials, which started in June 1981, shows how respectful towards judges Solidarność was. Leaders of the unofficial political party KPN (Konfederacja Polski Niepodległej) who decided to act openly, were accused, among other things, of attempting to violently overthrow the system of the People's Republic of Poland and inciting to acts directed against the unity of the allied states-for example, the Soviet Union. ${ }^{89}$ During the trial, they were several times released from the detention on remand by the Regional Court in Warsaw, but arrested immediately again by the Supreme Court-the Supreme Court judges were appointed for five year terms which made them prone to yield to political pressure. 'Solidarność Weekly' reported regularly on the case. The author clarifies that she supports the position taken by the Regional Court, not that of the Supreme Court. Still, the tone of reporting is respectful-however, we must remember the censorship which certainly did influence both the tone and content. ${ }^{90}$

In sum, CSOs before 1989 primarily advocated for the rule of law and monitored its implementation in part by taking an oppositional stance to the judiciary. However, they began to engage in the interactions and cooperation with judges that would become more common in the future.

\footnotetext{
${ }^{84}$ TYGODNIK SOLIDARNOŚć, April-December 1981.

${ }^{85}$ See STANOWSKa \& STRZembosz, supra note 23 , at 8.

${ }^{86} \mathrm{See} i d$. at $60-65$. Strzembosz argues that there is no reliable data on this issue but he provides information that at the request of the Minister of Justice, the Council of State dismissed twenty-five judges and accepted the resignation of eleven judges. The Minister also dismissed five judges-assessors. Finally, the Minister dismissed nine court presidents and vice-presidents from their positions.

${ }^{87}$ See Biuletyn $n r$ 1, KOMITET HelsińsKi w POLSCE, 1988, at 38, https://www.hfhr.pl/komitet-2/biuletyn/.

${ }^{88}$ See Jolanta Strzelecka, Cenzura przed sądem, 33 Tygodnik Solidarność, Nov. 13, 1981, at 1, 4.

${ }^{89}$ See Konfederacja Polski Niepodległej 1979-1990, InSTYTUT PAMIĘCI NARODOWEJ, https://ipn.gov.pl/ftp/wystawy/kpn/ pdf/plansze.pdf.

${ }^{90}$ See Wanda Falkowska, Sąd Najszybszy, 26 TygodniK Solidarność, Sept. 25, 1981, at 13.
} 


\section{Liberal Democracy - Time of Building (1989-2015)}

\section{New World. Independent Judges and Free Citizens in Charge - Background}

In 1989-2015, Poland evolved from an authoritarian socialist state to a liberal democracy. The historic breakthrough of 1989 began with the 'Round Table Talks' from February to April 1989 and the first (partly) free parliamentary elections in June 1989. The parliament passed laws introducing the National Council of the Judiciary and irrevocability of judges, both agreed during the 'Sub-table for Law and Courts Reform' works. The process led to the gradual implementation of separation of powers, judicial independence, a right to a court, and a fair trial. The reforms were shaped by the jurisprudence of the highest courts and Constitutional Tribunal, confirmed by the new 1997 Constitution but also complemented by the ratification of the European Convention for the Protection of Human Rights and Fundamental Freedoms, fulfilling pre-membership criteria and accession to the Council of Europe (1991), NATO (1999), and the European Union (2004).

After the collapse of the communist state, the discussion on the vetting procedure of judges took place, and were especially intensive, in 1989-1991. CSOs and the Polish Helsinki Committee took part in the discussion. In March 1990, the Minister of Justice asked the Committee for assistance in the verification of judges and prosecutors. ${ }^{91}$ In response, the Committee sent a detailed list of judges and prosecutors active in political cases under martial law-1981-1986. The material did not contain any evaluations but dry facts: The composition of the court and prosecutors appearing in the case, case number and date, what the case concerned, a summary of the verdict. The list included some hundred cases and became a reference point for the minister in the evaluation of candidates when replacing the positions of president and vice-president of the court. ${ }^{92}$

No vetting of adjudicating judges has ever taken place. Apart from the Supreme Court, where over sixty percent of judges were renewed, the judges in Poland remained the same. ${ }^{93}$ The new law introduced lifetime appointments as a guarantee of judicial independence, and the ideas of judges' lustration were criticized as inconsistent with this law, including by the ministry, Ombudsperson, and the National Council of the Judiciary. ${ }^{94}$ Instead, the possibility of 'autolustration' of the judicial community was introduced-cleansing the profession of 'black sheep' through disciplinary proceedings. However, the judiciary community did not do it, the statute of limitations expired, and the political solutions were not introduced. Years later, including in 2015, those in power, referred to this omission and accused current judges of having communist origins. A member of the Committee warned against this back in 1992:

This small group of judges not only goes unpunished, but also performs functions that require an exceptionally immaculate attitude in every respect. Some might say that there are so few of them, so why all the fuss? Even if there is one such judge, s/he casts a shadow over the entire judiciary. This way we will not build the much-needed authority of the third power. And without a well-functioning judiciary that enjoys social trust, democracy is impossible. ${ }^{95}$

\footnotetext{
${ }^{91}$ Aleksander Bentkowski, Ministrowi sprawiedliwości z pomoca, in Komitet HelsińsKi w POLSCE PRAWA CZŁOWIEKA, BIULETYN 9'90 (Mar. 23, 1990), at 8, https://www.hfhr.pl/wp-content/uploads/2015/11/biuletyn_nr09.pdf.

${ }^{92}$ Communication with Marek Antoni Nowicki, July 2021.

${ }^{93}$ In December 1989, the five-year term of office of the Supreme Court was shortened and ended on June 30, 1990. The new composition of the Court was appointed by the President of the Republic on June 4, 1990 - 57 judges, including twenty-two from the previous composition of the Court. See Adam Lityński, Historia Sądu Najwyższego, SĄD NAJWYższY (Aug. 29, 2018), http://www.sn.pl/osadzienajwyzszym/SitePages/Historia.aspx.

${ }^{94}$ See Krajowa Rada Sądownictwa, Stanowisko Krajowej Rady Sądownictwa w sprawie niezawisłości sędziowskiej $i$ niezależności sądów, in Komitet HelsińsKi w Polsce, PraWA CZŁowieKa. BIUletyn 9'90 (Apr. 4, 1990), at 9-12, https://www.hfhr.pl/wp-content/uploads/2015/11/biuletyn_nr09.pdf; Interview with Aleksander Bentkowski, Minister of Justice, "Masa problemów," 15 Tygodnik Solidarność, Apr. 13, 1990, at 11.

${ }^{95}$ Marek Antoni Nowicki, Sądzić sędziego?, 1 TygodniK SolidARnoŚć, Jan. 3, 1992.
} 
Throughout the years the judiciary struggled with problems that led to the critique of its performance and controversies that are still in place. If we adopt the convincing concept of judicial capacity, ${ }^{96}$ a well-functioning judiciary should balance independence, competence, accountability, and efficiency. In Poland, an attentive observer would notice that the emphasis was placed over the years mainly on judicial independence $e^{97}$ and efficiency - the concern of subsequent governments due to excessive length of proceedings. ${ }^{98}$ Because of systemic changes, the caseload increased from 2 million in $1989^{99}$ to 15 million in $2015 .{ }^{100}$ In the same period, the number of judges increased from four to ten thousand. ${ }^{101}$ Professional competence was built mainly based on traditional methodology without systemic and critical interpretation of the law and so-called soft, extra-legal skills. Finally, accountability of the judiciary, particular courts, and judges was not a focus-quite frankly, it was hardly known as a concept and often mistaken for, and limited to professional/disciplinary responsibility. ${ }^{102}$

Politicians, and sometimes academics, blame judges for not undertaking the proper judicial reform. ${ }^{103}$ However, in Poland, it is the executive with the Ministry of Justice (MoJ) that is legally responsible for the administration of justice. Judicial governance is only partially left to courts. In fact, it is exercised mostly by politicians.

The judiciary has no representation at the state level; a counter partner for relations with the legislature and the executive, it has no think tanks to conduct research and design reforms and no legislative initiative to initiate changes in the law. These tasks could be partially fulfilled by the NCJ, but it was not conceived of as a body representing judges and managing courts, but as a platform where representatives of various authorities meet with duties limited mainly to appointing judges, giving opinions on draft laws, and ensuring the independence of the judiciary.

On one hand, there were calls from CSOs for the NCJ to expand its role as a think tank and initiator of research and reform, but the Council performed this role to a very limited extent. ${ }^{104}$ On the other hand, both the Council and judicial associations initiated discussions on changing the management model for the judiciary from ministerial to independent be it by the Supreme Court or the National Council of the Judiciary with significantly extended powers. ${ }^{105}$ But the topic was never seriously addressed by the rulers.

\footnotetext{
${ }^{96}$ See generally OPEN SOCIETy InSTITUTE, Monitoring the EU Accession Process: Judicial Capacity (Full Report) (2002), https://www.opensocietyfoundations.org/publications/monitoring-eu-accession-process-judicial-capacity.

${ }^{97}$ Poland was not an exception in the region. See Michal Bobek, The Fortress of Judicial Independence and the Mental Transitions of the Central European Judiciaries, 14 Eur. PUB. L. 1, 99-123 (2007). See also James E. Moliterno, Lucia Berdisová, Peter Čuroš \& Ján Mazúr, Independence Without Accountability: The Harmful Consequences of EU Policy Toward Central and Eastern European Entrants, 42 FordHAM INT'L L.J. 481 (2018).

${ }^{98}$ There are no detailed surveys comparing, for instance, the number of positions by various bodies on particular four elements, but many years of observation of the judiciary, changes in the law, research, and literature on the subject allow the author to form this, even if general, view.

${ }^{99}$ See PrZyszłość Polskiego Wymiaru Sprawiedliwości (AdAm Zieliński \& Marek ZubiK, eds., 2002 ), at 120.

${ }^{100}$ Andrzej Siemaszko, Paweł Ostaszewski \& Justyna Włodarczyk-Madejska, Tendencje wplywu spraw do polskich sądów powszechnych, INSTYTUT WYMiaRU SPRAWIEDLIWOŚCI (2019), at 8, https://iws.gov.pl/wp-content/uploads/2019/05/IWS-Siemaszko-OstaszewskiW\%C5\%82odarczyk-Madejska-Tendencje-wp\%C5\%82ywu-spraw-do-polskich-s\%C4\%85d\%C3\%B3w-powszechnych.pdf.

${ }^{101}$ See Paid employees in common courts [Jednostki sądownictwa powszechnego i zatrudnieni sędziowie], database prepared by the Ministry of Justice, isws.ms.gov.pl/pl/baza-statystyczna/opracowania-wieloletnie/download,2853,13.html.

${ }^{102}$ The word 'accountability' had no direct equivalent in Polish. The word 'odpowiedzialność' (responsibility) was used. Such an equivalent of accountability—rozliczalność-has been proposed, but has only partially caught on.

${ }^{103}$ See Bobek, supra note 97. See also Adam Czarnota, Rule of Law as an Outcome of Crisis, 8 HaGUE J. Rule L. 311-21 (2016). However, Czarnota's criticism is, in my opinion, partly unfounded and exaggerated.

${ }^{104}$ Łukasz Bojarski, Rola działań i dorobku organizacji pozarządowych $w$ kształtowaniu programów szkoleń dla sędziów, Krajowa Rada Sądownictwa. KWARTALniK (2013/3).

${ }^{105}$ See Konferencja Krajowej Rady Sądownictwa i Senatu RP, Model Nadzoru nad Działalnością Sądów i Pracą Orzecznicza Sędziów (Jan. 8, 2014); Okrąły Stół dla Sądownictwa, Dlaczego chcemy obrad Okragłego Stołu? Idea projektu i program pierwszej debaty, IUSTITIA (Feb. 11, 2012), https://www.iustitia.pl/porozumienie-szisp/501-okragly-stol-dla-sadownictwa.
} 
During the entire period, there was very little research and empirical studies on the judiciary. ${ }^{106}$ The public administration and Academia did very little research on the actual functioning, legitimacy, perception of the courts, on working conditions, the role of the court staff, the court administration, and other similar topics. Most subsequent governments lacked a strategic approach to the judicial reform. ${ }^{107}$ In 1990-2015 ministers of justice alternated, on average, once a yeartwenty-five changes in twenty-five years. ${ }^{108}$ Instead of building a common bipartisan strategy, ministers experimented, introducing fast and not adequately prepared changes often based more on the intuition and experience of temporary employees in the $\mathrm{MoJ}$ than on the research, surveys, and hard data. ${ }^{109}$ Institutional memory was missing. ${ }^{110}$

For the assessment of the role which judges could have played in the reforms of the system, it is relevant to understand that for years they were treated by the changing rulers as an object of politics rather than a partner. The judges' workload was constantly increasing due to the widening of the 'right to court.' At the same time, judges faced problems in ensuring the appropriate organization and resources for their work. I share the opinion that the judiciary could have done more within the framework of its powers. However, the model of administrative supervision ${ }^{111}$ over the courts by the Ministry of Justice adopted in Poland significantly limited judges' initiative. ${ }^{112}$

This governments' withdrawal, or 'minimalism' when it comes to the research and strategic reform of the judiciary and the inactivity of the judiciary itself has led to the considerable involvement of the CSOs in matters that would typically be left to other entities. Civic activities after 1989 developed rapidly. The growth of the sector was significant. New laws on associations and foundations were passed and the number of CSOs expanded greatly from a number close to zero in 1989 to about 100,000 active organizations in $2018 .^{113}$

Finally, significant development helped establish particular kinds of CSOs-judicial associations, first 'Iustitia' and later other organizations that are smaller but essential for the development of the judiciary and its relations with society. Association of Adjudicating Judges, 'Iustitia', founded in 1990, was the first independent judicial association in Poland. ${ }^{114}$ The first president of Iustitia, Supreme Court judge Teresa Romer describes its objectives as follows:

The assumption was to provide the society with judges representing not only the highest professional, but also the highest moral and intellectual level. We wanted to have the best judges in the Association, who would set an example to others. We did not want to create a "mass organization." 115

\footnotetext{
${ }^{106}$ See Michał Szwast \& Barbara Grabowska-Moroz, Instytut Wymiaru Sprawiedliwości - niezbędny think tank, czy niepotrzebny anachronizm?, HelsińsKa FundaCja PraW CzŁoWIEKA (2015). See also Łukasz Bojarski, Fakty nie maja sity przebicia, PRAWNiK, Dziennik GazeTa Prawna C6-C7 (Nov. 13, 2015).

${ }^{107}$ Some ministers undertook attempts of building the strategy but these processes were stopped for various reasons.

${ }^{108}$ See Wolna Encyklopedia, Ministerstwo SPRAWIEDLIWOŚCI (POLSKA), WIKIPEDIA, https://pl.wikipedia.org/wiki/Ministerstwo_ Sprawiedliwo\%C5\%9Bci_(Polska)\#Lista_ministr\%C3\%B3w_sprawiedliwo\%C5\%9Bci_i_prokurator\%C3\%B3w_generalnych.

${ }^{109}$ See Dawid Sześciło \& Jarosław Bełdowski, Reformatorzy i hamulcowi: przegląd działań ministrów sprawiedliwości po 1989 $r$., Forum ObyWatelskiego Rozwoju (2010).

${ }^{110}$ It sounds anecdotal, but MoJ's employees brought by new governments phoned CSOs activists_ including author- to inquire about works undertook by their predecessors.

${ }^{111}$ The common usage of this legal term is significant: "administrative supervision" (nadzór administracyjny) and not for instance "judicial governance."

${ }^{112}$ Interestingly, sixteen Voivodship Administrative Courts and the Supreme Administrative Court (SAC) have separate systems of governance in which the President of the SAC plays the role of the MoJ. And those courts have been rated as better than common courts, both in terms of their performance and the working conditions of judges.

${ }^{113}$ See Beata Charycka \& Marta Gumkowska, The Capacity of NGOs in Poland-Key Facts, KLON/JAwOr Association, 3 (2018), https://api.ngo.pl/media/get/110579.

${ }^{114}$ Association of Polish Judges "Iustitia" presently gathers over 3500 members, one-third of judges. See Iustitia Stowarzyszenie Sędziów Polskich, About Us, IUsTITIA, https://www.iustitia.pl/en/about-us/about-us.

${ }^{115}$ See Interview by Grzegorz Szacoń with Maria Teresa Romer, IUSTrTIA 1(1)/2010 (Dec. 31, 2011), https://www.kwartalnikiustitia. pl/pozostaje-szeregowym-czlonkiem-\%e2\%80\%9eiustitii-i-nie-narzekam-ztego-powodu-z-sedzia-maria-teresa-romer-rozmawia,2122.
} 
Other CSOs had also played a role in establishing and the development of Iustitia. Representatives of the Polish Helsinki Committee organized ${ }^{116}$ a visit to Poland of Judge François Guichard, President of MEDEL, the organization grouping judicial associations in Europe which accepted Iustitia as its member. ${ }^{117}$ Stefan Batory Foundation supported Iustitia with financial grants. Other CSOs, especially the Helsinki Foundation for Human Rights, had invited judges to common projects-several of them are mentioned below. And as declared by Judge Romer, Iustitia was not a judicial trade union; it was for many years an organization focused on judicial independence, but also on competence, accountability, and judicial ethos. Judges from Iustitia called regularly for the judicial reforms.

\section{Together or Separately? Cooperation, Interactions, Communication between the Judiciary and CSOs}

In January 1990, some members of the Polish Helsinki Committee founded the Helsinki Foundation for Human Rights (HFHR) - a CSO that played a significant, often innovative, role in building the relationship between the justice system and civil society. ${ }^{118}$ The HFHR dedicated itself to building the division of powers and independence of courts through advocacy, legislative proposals, and training.

The HFHR pointed out the necessity for fundamental changes resulting from the state of the judiciary as inherited from the People's Republic. Ewa Łętowska, ${ }^{119}$ after serving as the first Polish Ombudsperson (1988-92), cooperated with HFHR for some years and diagnosed the situation with a subtlety rare at that time. ${ }^{120}$ Writing about the educational needs of judges and the role to be played by CSOs, she summarized previous experiences and future needs, pointing out that judges were seen, and saw themselves, as a part of the state apparatus. They lacked the ability of judicial review and direct application of the constitution and international standards. According to Łętowska, judges lacked knowledge but mostly needed practical legal interpretation skills and adequate attitudes - a sense of core values built on human rights and the rule of law. ${ }^{121}$

Łętowska drew attention to transparency as a condition for the legitimacy of courts and to an obligation of judges and courts to conduct dialogue with society and to report on the exercise of judicial power. Her writings from the mid-1990s read like a list of tasks that were undertaken later for years, often by CSOs. However, Łętowska also acknowledges the judiciary as a discerning target group and formulates conditions that CSOs must fulfill to be accepted as partners and work with judges efficiently. The HFHR's activities mentioned below, designed specifically for judges or undertaken with judges, show diverse approaches. ${ }^{122}$ These are selected examples from a much bigger pool of activities of more organizations. ${ }^{123}$

\footnotetext{
${ }^{116}$ Interview with Marek Antoni Nowicki (Dec. 2020).

${ }^{117}$ See Magistrats Européens pour la Démocratie et les Liberties, Member Organizations of MEDEL (Mar. 1, 2012), https://www.medelnet.eu/index.php/association/member-organisations. Interview with Marek Antoni Nowicki (Dec. 2020).

${ }^{118}$ See HelsińsKa Fundaja Praw CZŁowieKa, https://www.hfhr.pl/fundacja/. The Helsinki Committee remained a group of people that during important public debates issue laconic statements underlying the importance of fundamental rights.

${ }^{119}$ Professor of law, later also a judge of the Supreme Administrative Court and the Constitutional Tribunal.

${ }^{120}$ Mainly in internal HFHR documents, but also in some academic writings. See Ewa Łętowska, Peryferyjne zmagania $\mathrm{z}$ nowoczesnym państwem prawa. O transformacji w Polsce w latach 1988-2016 (unpublished manuscript). This was partly translated and published without historical background as Ewa Łętowska, Polen: Nedbrytningen av rättsstaten 36-61, in Petra BÁrd, Johan Hirschfeldt, Ewa Łętowska, Laurent Pech \& Fredrik Sterzel, Hoten Mot Rättsstaten i EUROPA (2017).

${ }^{121}$ Ewa Łętowska, O potrzebie i możliwościach kształcenia sędziów, w ramach działalności edukacyjnej NGOs (2000) (unpublished manuscript).

${ }^{122}$ Here, I borrow fragments from an expert opinion. See Lukasz Bojarski, Communication Strategy of the Ukrainian Judiciary: Report and Recommendations (2019) (unpublished manuscript) (on file with author).

${ }^{123}$ For examples from other CSOs see below.
} 
The HFHR published for three years (1993-95) a periodic bulletin "Do You Know ...", distributed for free among journalists with the encouragement to be quoted without providing the source. It was an 'ABC' of the 'rule of law standards' and 'judicial review' based on current case law. ${ }^{124}$ A team of authors led by Łętowska informed in plain language the media, society, and judges - especially from the lower courts-about the role of courts and judicial review in a democratic society on the national and international level. The bulletin taught readers about fundamental rights and fair trial standards. It taught the media to report on legal issues. For citizens, it showed that one person could win against a state in the court of law. For judges, it showed their essential role and the tools and powers they had in their hands. ${ }^{125}$

Judges appeared in the HFHR educational projects as both presenters and participants. As lecturers often acted as judges of the highest courts. In the ordinary courts and among teachers, CSOs promoted inviting children and youth to courts and inviting judges to schools. Judges participated in events exclusive to judges, such as courses on human rights and moot courts based on the European Court of Human Rights (ECtHR) standards, with other legal professions in seminars and conferences, and those addressed to the general public-a post-graduate Human Rights School organized for seventeen years, 1991-2008, by the HFHR. ${ }^{126}$ During these courses, participants analyzed the role of courts in human rights protection and judicial review in detail.

The HFHR also organized a series of meetings—called 'a salon'—for judges and journalists who could listen to presentations and debate while sitting around the tables and drinking tea. They discussed cooperation and proper understanding of the professional roles of both groups. During 'salons' for judges, they had an opportunity to meet with experts and talk, often for the first time, about subjects like psychology or the language of the courtroom.

Another project, "Journalist in a Court," encompassed a series of two-day workshops for local judges and journalists in different jurisdictions. It was a joint project of HFHR, the Stefan Batory Foundation, and Iustitia. The agenda included a guided discussion on the problems and hardships of cooperation thus far, mutual expectations, and a simulation of a court hearing where journalists played roles of trial actors and judges were assigned the roles of the press, radio, and television journalists. The program brought different changes. For instance, it inspired similar meetings of judges' trainees with journalists in the Poznan Regional Court. Adding media relations to the curriculum helped to improve their mutual contacts. A judge who received 'the best journalist' title during one seminar was chosen as his court's spokesperson soon after the seminar. A journalist awarded 'the best trial actor' title became a press officer in the court in Opole after the seminar. ${ }^{127}$ Furthermore, the judge who co-hosted the project later became a star of the educational television series "Judge Anna Maria Wesołowska."

This shows that-thanks to CSOs that acted as an intermediary-two groups that were often unreceptive to each other-free reporting on courts' activities and 'social control' of the courts by the free media were new phenomenon-had a chance for constructive dialogue and stepping into someone else's shoes to better understand mutual relations, expectations, social roles, and misrepresentations which made fair and well-informed legal reporting difficult. Also projects like this, which were organized by CSOs with Judges Associations as partners, were a step forward in their cooperation.

The HFHR also acted as a legal think tank in research and human rights monitoring. For instance, a survey conducted by the HFHR in district courts in 1998 showed the terrible working conditions of judges and the court staff, the misery of the court buildings and infrastructure, and

\footnotetext{
${ }^{124}$ Supported by The German Marshall Fund and also published in three annual volumes.

${ }^{125} \mathrm{Based}$ on the reading of three annual volumes.

${ }^{126}$ See Laura Koba, Prawa CZŁowieka w edukacji w OKresie transformacji ustrojowej w Polsce, Oficyna WYDAWNICZA VOLUMEN, WARSZAWA (2014).

${ }^{127}$ See Łukasz Bojarski \& Grzegorz Wiaderek, Szkolenie sędziów: wspótpraca z organizacjami pozarządowymi, in SPRAWNY SĄD. ZBIÓR DOBRYCH PRAKTYK, CZ̨̨Ść DRUGA (Łukasz Bojarski ed., 2008).
} 
the weaker position of courts compared to the legislative and executive authorities. The report, presented in parliament, aided in gaining a budget increase for the courts. ${ }^{128}$ This kind of approach indicated to judges that CSOs understood and appreciated the role of courts. Apart from criticizing the quality of judges' work, length of the proceedings, or lack of transparency, they also advocated for decent working conditions for judges. Many other surveys and research projects were conducted over the years, including within the multi-year project "Monitoring of the legislative process in the area of justice."

In 2002-2009, the HFHR and Justitia cooperated on the "Team for the Improvement of the Functioning of the Judiciary." ${ }^{129}$ Around fifteen to twenty judges, levels ranging from the lowest to highest courts, sought to identify, describe, and popularize best administrative and management practices in the judiciary. At the same time, executive power sometimes preferred to point out the "collapse of the judiciary" (zapaść wymiaru sprawiedliwości), a commonly used expression at the time. Working pro bono on weekends, the group identified such best practices already adopted at the level of courts, then analyzed and described them in an accessible language according to the template, popularized them with newspapers, books, and conferences, and hoped that they would be widely disseminated or standardized on the country level. ${ }^{130}$

The team believed that proven commonsense solutions, sometimes in small matters, could find their way to other courts by showing that many changes could be introduced instantly, independently, without a need for legislative changes, often without much money, and without a need of seeking official approval from any higher echelons. The team's work has inspired other judges and court presidents to implement best practices and design new ones. ${ }^{131}$ The project proved that at least part of the judges wanted to engage and change the judiciary from the inside. It also indicated confidence in CSOs by some judges who decided to work together, sharing their experiences and ideas.

The above account concentrated on the HFHR, but other CSOs also focused on different aspects of the judiciary. The following examples do not exhaust the wealth of endeavors.

In the 1990s, the Polish Section of the International Commission of Jurists (ICJ), the lustitia, and the Bar organized a series of 'Constitutional Seminars for Judges and Advocates' in all appellate jurisdictions. Since 2000, the ICJ ran an annual competition for the European Judge Honorary Title, addressed to judges who "in the written grounds for their judgments or requests for preliminary rulings, make references to arguments resulting from: The Polish Constitution, the European Convention of Human Rights, EU law, or international law in the broad sense."132

In the 2000s, the FOR Foundation conducted numerous surveys of the judiciary and advocated for adequate reforms. Topics included a ranking of courts' websites, communication of courts with citizens, the effectiveness of the judiciary in the light of international and national research, review

\footnotetext{
${ }^{128}$ See Łukasz Bojarski \& Jerzy Swaton, Warunki pracy sądów rejonowych: raport $z$ monitoringu, HELSIŃSKA FUNDACJA Praw CzŁowieka (1999) (The District Courts' Conditions of Work: Monitoring Report; summary and table of contents is also available in English and Russian).

${ }^{129}$ These projects were supported by the Stefan Batory Foundation. See About us, Fundacja Batorego, STEFAN BATORY FOUNDATION, https://www.batory.org.pl/o-nas/o-nas/.

${ }^{130}$ The team published three collections of best practices-two in 2004 and one in 2008. See SPRAWNY SĄD. ZBIÓR DOBRYCH PRAKTYK, CZ̨̨Ść DRUGA (Łukasz Bojarski ed. 2008); SPRAWNY SĄD. ZBIÓR DOBRYCH PRAKTYK, WYDANIE DRUGIE (Łukasz Bojarski ed. 2004) and SPRAWNY SĄD. ZBIÓR DOBRYCH PRAKTYK (Łukasz Bojarski ed. 2004).

${ }^{131}$ The project inspired an extensive program of pilot courts conducted in the framework of the National School of Judiciary and Public Prosecution. See Ewa Bałuch-Baranowska, METodyKa ZARZĄDZANIA JEDNOSTKAMI WYMIARU SPRAWIEDLIWOŚCI: Studium PRZyPadKu NA PRZYKŁadzie SĄDU Rejonowego Katowice-Zachód w Katowicach (Krzysztof Hejosz ed., 2014); Jarosław Gwizdak, 100 Idei dla Polski. Reforma Wymiaru Sprawiedliwości, WszYstKo Co NaJWAŻNIEJSZE (Dec. 18, 2016), http://xn-wszystkoconajwaniejsze-b0e.pl/.

${ }^{132}$ Zbigniew Lasocik \& Monika Adamczyk, Konkurs o Tytuł Honorowy "Sędzia Europejski”. Cz. 2, KrajOWA RadA SĄDOWNICTWA. KWARTALNIK (2016/1).
} 
of the activities of the Ministers of Justice after 1989, public availability of court decisions, periodic evaluation of judges' work, and transparency and efficiency of courts' work. ${ }^{133}$

Since 2010, the Court Watch Polska Foundation has trained citizens who would like to conduct observations of court hearings. As of 2020, over three thousand people have observed more than 45,000 hearings in 220 towns. The Foundation publishes its findings and presents them to judges. ${ }^{134}$ Beginning in 2015, the foundation also awards the Citizen Judge of the Year Award to those judges "who have distinguished themselves in a special way in the past year for citizens."135

Foundation E-państwo is one of the CSOs that have been regularly submitting 'the right to information requests' to courts and exposing their lack of transparency. ${ }^{136}$ For years Polish courts were non-transparent, both with regard to court rulings, which are not available in data basis or publications, and information on court operations. ${ }^{137}$

As already indicated, the role of judicial associations became very important. They ran with other CSOs different joint programs mentioned above. They were the part of the judiciary open to new ideas and promoting them among judges. For example, in 2010s judges conducted several projects with CSOs on non-discrimination issues, including the development of a handbook for judges or joint workshops of judges and representatives of CSOs advocating for discriminated minorities. ${ }^{138}$ Similarly, as partners, they organized workshops for judges on the Charter of Fundamental Rights of the EU, in respect of which the then-ruling parties expressed ill-founded doubts and reservations. ${ }^{139}$ Cooperation of CSOs with judges' associations also resulted in establishing contacts with particular courts and inspired those court presidents who saw the need for reforms to introduce on their initiative various practical organizational solutions in certain local courts. ${ }^{140}$

Finally, in 2014-2015, the Institute for Law and Society (INPRIS), ${ }^{141}$ in cooperation with the National School of Judiciary and Public Prosecution, ${ }^{142}$ conducted the project "Together or separately? Cooperation, interactions, communication between the judiciary and NGOs." It included the conference in 2014 and was the first meeting of this kind-over a hundred judges and activists from various CSOs openly shared, on equal footing, feedback on their activities — each workshop began with presentations of two judges and two representatives of the CSOs. ${ }^{143}$ It showed the great

\footnotetext{
${ }^{133}$ See Forum Obywatelskiego Rozwoju, RAPORTY FOR, https://for.org.pl/pl/publikacje/raporty-for.

${ }^{134}$ See Stanisław Burdziej \& Bartosz Pilitowski, Polskie sądy z perspektywy obywateli - podsumowanie pięciu lat Programu "Obywatelski Monitoring Sądów" [Polish Courts from the Perspective of Citizens - Summary of Five Years of the "Citizen Court Monitoring” Program], Krajowa Rada SąDOWnictwa. Kwartalnik (2014/5).

${ }^{135}$ See Citizen Judge of the Year, Fundacja Court Watch POLSKa (last visited Aug. 31, 2021), https://courtwatch.pl/en/ action-areas/citizenss-sedzia-year/.

${ }^{136}$ Curently (2021) Foundation changed its name to Fundacja Moje Państwo. FundaCja Moje Państwo, https:// mojepanstwo.pl.

${ }^{137}$ See Michą Jagielski \& MAREK NieduŻAK, PublicZna dostęPNOŚć ORZECZEŃ SĄDOWYCH (Forum Obywatelskiego Rozwoju. 2010), https://for.org.pl/upload/Nowy_Wymiar_Sprawiedliwosci/Raport_Publiczna_dostepnosc_orzeczen_sadowych.pdf.

${ }^{138}$ Łukasz Bojarski, Dorota Pudzianowska \& Jarosław Jagura, Niedyskryminacja w Praktyce Sędziowskiej: Projekty Organizacji Obywatelskich, KRAJOWA RADA SĄDOWNICTWA. KWARTALNIK (2016/3), http://www.krspl.home.pl/admin/files/ kwartalnik/krs_03_2016_druk_prv.pdf.

${ }^{139}$ See Łukasz Bojarski, Dieter Schindlauer \& Katrin Wladasch, The Charter of Fundamental Rights As a Living INSTRUMENT: MANUAL (2014), https://www.archive.equineteurope.org/IMG/pdf/cfreu_-_the_charter_of_fundamental_ rights_as_a_living_instrument.pdf.

${ }^{140}$ Several examples are significant, for instance Ryszarda Stasiak, president of the District Court in Płońsk and author of numerous best practices. See Łukasz Bojarski, SpRAWNy SĄD. ZBIór DOBRYCH PRAKTYK, CZĘŚć DRUGA (2008). Tomasz Kałużny, president of the district court in Białystok who was also an author of best practices, then worked within the framework of EU programs; Jarosław Gwizdak, president of the District Court Katowice Zachód and the first laureate of the title "Citizens Judge of the Year." See Jarosław Gwizdak, 100 Idei dla Polski. Reforma Wymiaru Sprawiedliwości, WszYstKo Co NAJWAŻNIEJSZE (Dec. 18, 2016), http://xn-wszystkoconajwaniejsze-b0e.pl/.

${ }^{141}$ See INSTITUTE FOR LAw \& SOCIETY INPRIS, http://www.inpris.pl/ (last visited Sept. 19, 2021).

${ }^{142}$ See Krajowa Szkoła Sądownictwa i Prokuratury, KSSIP, https://www.kssip.gov.pl/ (last visited Sept. 21, 2021).

${ }^{143}$ See Łukasz Bojarski \& Grzegorz Wiaderek, Razem czy osobno? Współpraca, interakcja, komunikacja wymiaru sprawiedliwości i organizacji pozarządowych, Materiały konferencyjne INSTITUTE FOR LAW \& SOCIETY INPRIS (2014),
} 
variety of CSOs' activities related to the judiciary. ${ }^{144}$ Examples of areas covered during different workshops included:

- CSOs' participation in systemic measures concerning the judiciary, such as legislative processes, and court audits, access to information on the court activities and judges;

- CSOs research projects and monitoring of the judiciary (activities of courts, communication with citizens, judicial appointments);

- Trial observation and its different faces - basic civic trial observation, professional observation of high-profile cases, program 'Innocence';

- CSO's involvement in court trials, amicus curiae brief and the like, ${ }^{145}$ bringing impact cases (strategic litigation); ${ }^{146}$

- Influencing curriculum ${ }^{147}$ and conducting training/seminars for judges ${ }^{148}$ as well as public education on the judiciary conducted by different CSOs;

- Cooperation of CSOs with judicial associations.

During the conference both groups openly discussed problems, provided feedback, sought solutions, and jointly formulated recommendations. I will mention just two of them:

It is valuable to establish cooperation between the judiciary and CSOs in the form of regular meetings between them, allowing for exchange of experience and timely feedback. Such cooperation can be of particular importance in educational projects and could involve national schools of judiciary.

Judges' associations are a natural ally for CSOs. Judges' associations and civil society organizations shall make every effort to build efficient communication channels. This will enable judges to understand CSOs and CSOs to better understand standpoints and opinions of judges. ${ }^{149}$

Regardless of the, somewhat mixed, assessment of the entire twenty-five-year period, it is worth noting that many interesting initiatives, in large part inspired by CSOs, happened "at the last minute," in the years 2014-15. The National Council of the Judiciary and its judicial majority - seventeen out of twenty-five members-became more active in public debate and communicating with society. In 2015, the NCJ finally recognized CSOs as the natural allies in the efforts to maintain the independence of the judiciary. This was also appreciated by awarding some representatives of the civil sector with the highest medals of the Council-Meritorious for Justice System

http://www.inpris.pl/fileadmin/user_upload/documents/INPRIS-Sady-NGOs_ZAPROSZENIE-Program-wersja-do-rozsylki_ 1_.pdf.

${ }^{144}$ See Łukasz Bojarski, Razem czy osobno? Wspótpraca, interakcja, komunikacja wymiaru sprawiedliwości i organizacji pozarząowych, KRAJOWA RADA SĄDOWNICTWA. KWARTALNIK (2014/4).

${ }^{145}$ See Maciej Bernatt, Opinia przyjaciela sądu [amicus curiae] jako pomocnicza instytucja prawna w orzecznictwie sądów polskich, in SPRAWNY SĄD. ZBIÓR DOBRYCH PRAKTYK, CZĘŚć DRUGA (Łukasz Bojarski ed., 2008).

${ }^{146}$ For example, HFHR strategic litigation in case of assistant judges who were selected by NCJ for judicial positions in 2007 and whose appointment was refused by President Lech Kaczyński without clear legal basis.

${ }^{147}$ See Łukasz Bojarski, Rola działań i dorobku organizacji pozarządowych w kształtowaniu programów szkoleń dla sędziów, Krajowa Rada Sądownictwa. KWARTalnik (2013/3).

${ }^{148}$ For example, the Empowering Children Foundation has introduced a training module for judges, prosecutors and psychological experts in the field of participation of minors in the court proceedings. See Fundacja Dajemy Dzieciom Siłę, Materiały dla Profesjonalistów Pracujacych z Dziećmi Uczestniczacymi w Procedurach, =https://edukacja.fdds.pl/ course/view.php?id=164. The Polish Society of Anti-Discrimination Law (PSAL) established cooperation with the National School of Judges and Prosecutors. See Polskie Towarzystwo Prawa Antydyskryminacyjnego, MiSJA PTPA, http:// ptpa.org.pl/o-nas/misja/.

${ }^{149}$ See InSTITUTE FOR LAW \& SocIETy INPRIS, NGOs and the Judiciary-Watch Dog Activities, Interactions, Collaboration, Communication (Łukasz Bojarski \& Ewelina Tylec eds., 2016), https://ceeliinstitute.org/wp-content/uploads/2016/07/NGOs_ and_the_Judiciary_-_Final_Publication.pdf (an international project's report on similar subject that repeats a number of 2014' recommendations). 
-Bene Merentibus Iustitiae, which has never happened before. ${ }^{150}$ A couple of years before, the NCJ legal journal began to publish papers authored by CSOs' activists, summarizing different CSOs projects related to the courts, and providing feedback for judges based on projects' findings. ${ }^{151}$

The Ministry of justice was also involved in these efforts. In 2014, the Ministry adopted the 'Strategy for the modernization of the judicial area' in which civil organizations and communication between courts and citizens played an important role. Within the MoJ, the Social Council for implementation of the Strategy was established and met to discuss those issues. ${ }^{152} \mathrm{~A}$ joint team of the NCJ and the Ministry of Justice focused on communication between the courts and citizens and developed, in 2015, two relevant guidebooks. ${ }^{153}$ The team promoted transparency and openness to communication during meetings with judges in all appeal jurisdictions. ${ }^{154}$ The subsequent government after the 2015 elections did not continue any of mentioned initiatives.

\section{Far from Paradise}

The projects undertaken by the HFHR and other CSOs demonstrate the multifaceted approach. It targeted judges to show them what citizens expect from "old judges in new times," but it also aimed at strengthening the judges' sense of personal and professional agency and their authority. These projects were furthermore addressed to journalists and citizens so they would also understand the new role of the court in a democracy. Finally, it showed judges that CSOs were serious actors, critical 'watch dog' type, and supportive at the same time. The projects also proved the development of the relationship between judges and CSOs.

During the 2014 conference mentioned above, Ewa Łętowska argued in her keynote speech that judges should be open to cooperation, interactions, and communication with civil society not only because of the common good and other ideals, but because it was in the judges' own interest. In the era of tabloidization of the media and lack of involvement of lay members in adjudication, competent CSOs constitute for judges an open communication channel with the society. ${ }^{155}$

As one may notice, this message from 2014 essentially reiterated the theses from the early 1990s, proving that, although many actions were taken over twenty-five years to bring the courts and citizens closer, the process was far from being completed. It was only a coincidence that the conference reflected the state of relations and dialogue between courts, judges, and CSOs at a crucial moment, shortly before the new government led by PiS took power, as a result of which the relations between judges and organizations would take on a new shape.

How can one summarize twenty-five years of building democracy in the area of our interest? Both judges, courts, citizens, and CSOs have learned that the courts adjudicate millions of typical

${ }^{150}$ See Medal “Zasłużony dla Wymiaru Sprawiedliwości - Bene Merentibus Iustitiae,” WikiPEdiA: WolNA ENCYKLOPEDIA, (July 2, 2021), https://pl.wikipedia.org/wiki/Medal_\%E2\%80\%9EZas\%C5\%82u\%C5\%BCony_dla_Wymiaru_Sprawiedliwo\% C5\%9Bci_\%E2\%80\%93_Bene_Merentibus_Iustitiae.

${ }^{151}$ Several of those papers published in KRAJOWA RADA SĄDOWNICTWA. KWARTALNIK are mentioned throughout this Article.

${ }^{152}$ See Rada Społeczna ds. Strategii Modernizacji Przestrzeni Sprawiedliwości w Polsce, MinISTERSTwo SPRAWIEDLIWOŚCI, https://www.gov.pl/web/sprawiedliwosc/rada-spoleczna-ds-strategii-modernizacji-przestrzeni-sprawiedliwosci-w-polsce.

${ }^{153}$ See Sądowe ABC dla dziennikarzy [Judicial ABC for journalists], MinisTERSTwo SPRAWIEDLIWOŚCI (2015), https://www. arch.ms.gov.pl/pl/dzialalnosc/strategia/komunikacja/; Zbiór dobrych praktyk dla sądów powszechnych: Komunikacja $i$ wizerunek sądów [A collection of best practices for common courts: Communication and image of courts], MINISTERSTWO SPRAWIEDLIWOŚCI (2015), https://www.arch.ms.gov.pl/pl/dzialalnosc/strategia/komunikacja/.

${ }^{154}$ See Łukasz Bojarski \& Anna Twardowska, Kształtowanie polityki komunikacyjnej $i$ wizerunkowej sadu (prezentacja), WARSZAWA (Mar. 31, 2015) https://www.gov.pl/web/sprawiedliwosc/rada-spoleczna-ds-strategii-modernizacji-przestrzenisprawiedliwosci-w-polsce.

${ }^{155}$ See Łukasz Bojarski, Razem czy osobno? Współpraca, interakcja, komunikacja wymiaru sprawiedliwości i organizacji pozarządowych, KRAJOWA RADA SĄDOWNICTWA. KWARTALNIK (2014/4). 
cases, are the guarantor of fundamental rights, and exercise control over the other authorities. They also learned that courts and judges - as well as the general public - need civic organizations.

Many systemic reforms were undertaken since 1989. The country transited from a so-called people's republic to a liberal democracy. The 1997 Constitution consolidated the new system of justice. However, what was missing after the first period of dynamic reforms was a strategic and systemic approach to the reform of the entire justice system. Who is to blame? The 2021 ruling majority publicly railed against judges, who allegedly did not carry out the reform themselves and resisted reform for twenty-five years, until 2015. As shown above, this is not the whole truth. The State, as a whole, lacked strategic approach.

In the relative void created by the state's passivity, many areas of action were opening up for CSOs, with them replacing the state in a way. Apart from their specialized agenda, the organizations undertook activities that would not be needed if the legislative or executive powers had acted competently or acted at all. In some areas, organizations' efforts to improve standards and introduce new management practices took many years and were successful. In others, too little has been achieved. Let us mention two examples of evident successes.

Access to case law was significantly limited throughout 1990s and 2000s. What more, there were judgments, including the Supreme Court ones, that could only be read after purchasing commercial databases. Supreme Court judges, sometimes for additional remuneration, handed over these "unavailable rulings" to publishing houses—additionally elaborated, for example, with keywords. Many years of CSOs' efforts have finally led to changes, creation of databases and the widespread availability of case law. ${ }^{156}$

The participation of CSOs' representatives in court proceedings as observers or amicus curiae at first, especially in 1990s, raised doubts in the courts. In 1998 the first amicus curiae brief ever submitted by the HFHR - to the Regional Court in Płock — was rejected and returned by the court. ${ }^{157}$ In the absence of explicit legal provisions allowing for such briefs to be submitted to and relied on by the courts, judges had to be educated by CSOs about this procedural device. It was eventually successful as, eight years later, the Constitutional Tribunal in its ruling appreciated the role of CSOs in this capacity. ${ }^{158}$ Likewise, over time, the judges became accustomed to the observers.

It was also hard for CSOs' initiatives and output to break through to other circles, such as academia. A perfect example is the project OMKS: Research and monitoring of the vetting and selection process for the Constitutional Court Judges and other public posts. A coalition of CSOs executed that project since 2006, covering all appointments of CT judges, publishing detailed reports, being present in media, organizing public hearings, elaborating candidates' profiles, documenting and pointing out numerous shortages and weaknesses in both law and practice, as well as formulating recommendations. ${ }^{159}$ Scholars did not follow this subject. Suddenly, with the attack on Tribunal in late 2015, everything has changed. Numerous academic works and papers have begun to cover appointment procedures to the CT. Still, they refer to the previous ten years of CSOs' experience in the field only occasionally.

The discontinuity in the discussed period of transition from an autocratic to a democratic state is evident and a lot has changed-even significant judicial reforms introduced immediately after

\footnotetext{
${ }^{156}$ Michą Jagielski \& Marek NieduŻak, Publiczna dostęPNoŚć ORZeCZeŃ SĄDOwyCh (Forum Obywatelskiego Rozwoju. 2010).

${ }^{157}$ The brief was prepared in 1998 in the case of Bogusław Pyrak. It referred to the fair trial and pre-trial detention standards and was critical of the court. Years later, Bogusław Pyrak won the case before the ECtHR. See Piotr Lipiński, Pyrak agrawuje, MAGAZYN, GAZETA WYBORCZA (Oct. 30, 1998), https://classic.wyborcza.pl/archiwumGW/584317/PYRAK-AGRAWUJE; Pyrak v. Poland, App. No. 54476/00, (Feb. 12, 2008) =http://hudoc.echr.coe.int/eng?i=001-85002; Res. CM/ResDH(2014) 268, Execution of the Judgments of the European Court of Human Rights in Cases Against Poland (Dec. 4, 2014).

${ }^{158}$ See Bernatt, supra note 145; Constitutional Tribunal, Jan. 16, 2006, SK 30/05, at. I.8, III.2.2 (Pol.).

${ }^{159}$ See, e.g., Łukasz Bojarski, Katarzyna Furman \& Krzysztof Riedel, Wybory pod społeczną kontrola: Wybory sędziów Trybunału Konstytucyjnego, Generalnego Inspektora Ochrony Danych Osobowych, Rzecznika Praw Obywatelskich, Prokuratora Generalnego, Raport $z$ monitoringu, INSTITUTE FOR LAW \& SOCIETY INPRIS (2016).
} 
the restoration of sovereignty in 1989 had already been designed in the previous period, during Solidarność, and later by the Social Legislative Council mentioned above. ${ }^{160}$

There are also examples of continuity, like a lack of the openness of judges to communication with the public and CSOs and a lack of trust in community civic initiatives. Before 1989, CSOs advocated for an independent judiciary, but at that time judges were treated as agents of an undemocratic system and there were good reasons for it. There have been exceptions, mainly associated with the Solidarność era, but as a rule, relations between judges and civil society were minimal.

After 1989, certain CSOs reached out to judges. The judiciary, however, was not open to this contact and has remained hermetic. Its isolation from society continued, even though circumstances had changed. In 1990-2000s, active judges open to contact with the public or present in the media were criticized by their peers. There was a view that judges should not go outside the courtroom and that the verdict they issue are judges' only means of communication.

Instead, this was a continuity of mentalities. During the communist times, the judges regarded themselves as merely slightly glorified state officials wearing gowns. After the 1989 threshold, they immediately moved to the elevated spheres of presumed legitimacy which they had acquired only thanks to the institutional change. This was not accompanied by an understanding of the need to ground legitimacy of courts in communication and social understanding of the judicial role as well as judicial understanding of social context and social consequences of their decisions.

The quotation from the European Court of Human Rights (ECtHR) judgment shows that the importance of exchange between the general public and the courts was not sufficiently appreciated by the judiciary:

62. The Court notes that the appellate court suggested that journalists in judicial reporting were obliged to limit their reports to statements of fact and abstain from presenting their own opinions .... While the Court has stressed the importance of journalistic objectivity and balance in the context of judicial reporting ... it is of the view ... that journalists are free ... to formulate and disseminate their views and opinions on important issues involved in or connected with the subject-matter of cases under judicial consideration. In the same vein, it is important that the courts have an opportunity to obtain feedback on how their acts and judicial decisions are understood and regarded by the public. Such knowledge contributes to the quality of judicial decision-making and to a better understanding by society at large of the complexity of the issues involved in the administration of justice. ${ }^{161}$

After 1989, judges were learning their new role in a democratic society, including what civil society and accountability are. Common efforts of CSOs and judicial associations were bringing changes; but slowly. Additional difficulty was that judges felt as if they were under constant criticism-if not attack-by subsequent governments and were not receptive to feedback. Hence, the problems that CSOs encountered when trying to encourage judges to work or communicate with them. The CSOs' critical messages were often treated as an attack and the first reaction was usually defensive.

Even future-post the 2015 political attack-symbolic figures have shown signs of limited understanding of the role of CSOs. For instance, Małgorzata Gersdorf, president of the Supreme Court, refused in the past to disclose public information about the activities, and especially expenses, of the Supreme Court and was quite suspicious of the activities of CSOs demanding disclosure of information such as expenses related to the court's website, contracts signed by a court, or expenses paid by company credit cards. The Supreme Court's President was challenged by

\footnotetext{
${ }^{160}$ Barczyk et al., supra note 59.

${ }^{161}$ Semik-Orzech v. Poland, App. No. 39900/06, para. 62 (Nov. 15, 2011), =http://hudoc.echr.coe.int/eng?i=001-107446.
} 
CSO, foundation e-Państwo, in the administrative courts, lost the cases, and had to reveal the information - which, by the way, proves that Poland was a rule of law state. ${ }^{162}$

CSOs have learned that judges must trust a particular organization and its true commitment to the independent judiciary. According to judges, it is essential that NGOs balance the message and focus not only on that of the judiciary as they perceive them but stay objective and show that they understand positive aspects of the courts' operation and the complexities of the judicial work. This is often a controversial issue, as watchdog organizations tend to focus on negative aspects. ${ }^{163}$

There are different types of CSOs, including those which are not impartial, those supporting a given particular cause or a given party, or those simply outright biased. The category of 'civil society organization' is broad, and it is necessary for the courts to check the mission and objectives of the specific CSO in order to ascertain that it can be a good partner for co-operation. Judges have to avoid improper relations with CSOs in order to maintain their independence and impartiality. Distinctions should be made between CSOs which support the fair administration of justice in democratic society as a value in itself and those that advocate for interests of particular causes or groups of parties to a specific category of cases.

\section{Testing - Time of Defense (2015-2020)}

\section{I. 'Reform' Long-Awaited-Background}

The years 2015-2020 have been analyzed by scholars in both comprehensive works describing the Polish crisis chronologically ${ }^{164}$ and studies devoted to specific issues. ${ }^{165}$ This Article will only point out a few critical features of the governmental actions concerning the judiciary, which make the present situation especially threatening to the rule of law.

Strategy — an attack on the courts and their independence-officially 'reform' - seems to have been planned in detail. The Minister of Justice declared on public television in September 2016 that the judicial reform was prepared and ready, but it will be announced only "after solving the problem with the Constitutional Tribunal." 166 The government representatives argued that in the years of 2005-2007, when the PiS party was leading the governing majority, the CT stopped their reforms. PiS leaders, including Jaroslaw Kaczynski, developed the argument of "legal impossibilism," which meant that politicians want to reform the country, but the courts won't let them.

Focus on personnel and politicization of the courts - the government announced-in its wordsthe first systemic judicial reform after 1989. But in reality, it focused on the personal takeover of

\footnotetext{
${ }^{162}$ Piotr VaGla Waglowski, Fundacja ePaństwo właśnie wygrała dwie sprawy przed NSA - obie przeciwko I Prezesowi Sądu Najwyższego, VAGLA.PL (Sept. 11, 2012), http://prawo.vagla.pl/node/9855.

${ }^{163}$ InSTITUTE FOR LAW \& SOCIETY INPRIS, NGOs and the Judiciary-Watch Dog Activities, Interactions, Collaboration, Communication (Łukasz Bojarski \& Ewelina Tylec eds., 2016).

${ }^{164}$ See, e.g., Fryderyk Zoll \& Leah Worham, Judicial Independence and Accountability: Withstanding Political Stress in Poland, 41 Fordham InT'L L.J. 875 (2019); WojCiech SAdurski, Poland's Constitutional Breakdown (2019).

${ }^{165}$ See, e.g., Wojciech BiałogŁowski, Aleksandra DĘbowska, Monika Florczak-Wątor, Marzena Laskowska, BogumiŁ Naleziński, Agata Niżnik-Mucha, Maciej Pach \& JarosŁaw SuŁKowski, Konstytucyjny spór o granice

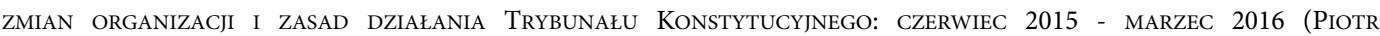
RadZiewicZ, Piotr TUleya, eds., 2017) (very detailed-over 500 pages covering 9 months-documentation and analyses of the first stage of the crisis around the Constitutional Tribunal).

${ }^{166}$ The government representatives argued that in the years 2005-2007, when the PiS party was leading the governing majority, the CT has stopped their reforms. PiS leaders, including Jaroslaw Kaczynski, developed the argument of "legal impossibilism," which meant that politicians want to reform the country but the courts won't let them. This is one of the reasons for the dislike of the courts. See also Łukasz Bojarski, Redefining Judicial Independence in Poland, CONSTItUTIONNET (Apr. 29, 2017), https://constitutionnet.org/news/redefining-judicial-independence-poland.
} 
courts and relevant institutions like the NCJ and its influence on decision-making processes. ${ }^{167}$ At the same time the efficiency indicators of the judiciary operations decreased significantly. ${ }^{168}$

Limiting independence - the government tried to take control over the courts using anti-communist rhetoric and branding its critics as post-communists. The politicians of the ruling coalition refused to accept that, in the division of powers formed by the Polish Constitution, courts are separate and independent and may control other authorities. The Prime Minister openly stated that there is something more important than the law, the "good of the nation and justice," and that the latter should prevail. ${ }^{169}$

Populism and hate speech-judges are consistently presented by the executive as a hermetic "caste" looking after their interests, as "elitist," as heirs and followers of communist criminals. ${ }^{170}$ Judges are attacked as a group and as individuals, against whom hate campaigns are organized either directly by the Ministry of Justice or by GONGOS. ${ }^{171}$ The Polish National Foundation, created by the government, spent millions of PLN on a defamation campaign against one of the governmental powers-judges. ${ }^{172}$ A group of people around the Deputy Minister of Justice - a judge himself - secretly planned to slander judges in media and social media. ${ }^{173}$ Public television produced the television series "The Cast," which is defamatory of judges. ${ }^{174}$

No scruples in assaults on judges and courts —an attack on the courts_-and individual judgesseems truly astonishing from the point of view of human decency standards, respect for the dignity of others, and also because of unacceptable language used by representatives of public powers. Moreover, it also amazes professionally for procedural reasons. Many fundamental legal changes were introduced in a flash, without public debate, without parliamentary discussion, without opinions, often at night, by MPs who acted like a voting machine-for example, without asking questions about what they were voting on. ${ }^{175}$

Despite this political, governmental attack, judges as a professional group were limited in their defense possibilities by the lack of official judicial representation on the state level and lack of the spokesperson for the judiciary. Local judges' assemblies and collegia, nor judges serving as spokespersons for particular courts, could not represent the whole judiciary, could not be a counterpart

\footnotetext{
${ }^{167}$ The process is described by Kim Lane Scheppele in writings on Hungary and Poland. See, e.g., Kriszta Kovács \& Kim Lane Scheppele, The Fragility of an Independent Judiciary: Lessons from Hungary and Poland-and the European Union, 51 Communist \& Post-Communist Stud. 189-200 (2018). See also Laurent Pech \& Kim Lane Scheppele, Illiberalism Within: Rule of Law Backsliding in the European Union, 19 CAMBridge Y.B. EUR. L. 3 (2017).

${ }^{168}$ See Obietnice a Rzeczywistość: Statystyki Sądów Rejonowych po Pięciu Latach Reform, IUsTiтIA (2021).

${ }^{169}$ See television interview with Mateusz Morawiecki, Prime Minister of Poland, DW Conflict Zone (Feb. 16, 2017), $=$ https://www.youtube.com/watch? $\mathrm{v}=\mathrm{HPp} 7 \mathrm{uVm}$-vSk. Morawiecki confirms the words of his father, MP, spoken in the Parliament, that "law is not sacred, good of the nation is above it" and uses the example of Nazi Germany, as a country that followed law.

${ }^{170}$ See interview with Marcin Warchoł, Deputy Minister, Koniec z sędziokracja, "W Sieci," (May 29, 2017-June 06, 2017).

${ }^{171}$ See, e.g., Justice Under Pressure-Repressions as a Means of Attempting to take Control over the Judiciary and the Prosecution in Poland. Years 2015-2019, IUsTiTia RAPORTY (Jakub Kościerzyński ed., 2020), https://www.iustitia.pl/en/ activity/informations/3724-report-justice-under-pressure-years-2015-2019.

${ }^{172}$ The defamatory campaign of the Polish National Foundation (PFN) entitled "Just Courts," conducted with public funds that were provided by State Treasury enterprises. At least from April 2019 until June 2021 this was not available on the PFN website nor even listed. See POLSKA FundaCJA NARODOWA, www.pfn.org.pl (last visited Sept. 21, 2021).

${ }^{173}$ See Maria Pankowska, Smear Campaign Coordinated by the Ministry of Justice, Aimed to Discredit Polish Judges, Discovered, OKO PRESS (Aug. 27, 2019), https://oko.press/why-did-the-polish-deputy-minister-of-justice-resign-everythingyou-need-to-know-about-the-piebiak-scandal/.

${ }^{174}$ See producer's information, translated by author, “A para-documentary series about people wronged by 'the system', the eponymous caste, or connections between judges, prosecutors, and businessmen .... The lawyers' job here is to find new evidence, get the trial reviewed, and prove that the previous verdict was rigged." See KASTA (THE CAST), https://vod.tvp. $\mathrm{pl} /$ website/kasta,50162540.

${ }^{175}$ See Ustawa w 2 godziny 20 minut: XIII Komunikat Obywatelskiego Forum Legislacji podsumowujący aktywność legislacyjna rząów Zjednoczonej Prawicy, Sejmu VIII kadencji i Senatu IX kadencji (2015-2019), FUNDACJA IM. STEFANA BATOREGO (2019), https://www.batory.org.pl/upload/files/Programy\%20operacyjne/Forum\%20Idei/Komunikat_2019-1.pdf.
} 
to other powers, and could not speak on behalf of the judiciary and take part in the political media programs where judges were attacked in their absence.

One could expect the NCJ to be such a body. However this would be a mistake, since NCJ is not a judicial body but a mixed one with members from other powers. Furthermore, this particular body might be seen as conservative for most of the time, its openness to the outside world, including academia, CSOs, and the legal profession, was very limited. It preferred to discuss issues in its own circle. ${ }^{176}$ It begun to rapidly change once the judiciary was attacked, but that doesn't excuse the earlier inaction.

As regards CSOs, the governmental 'reform plan' also included thwarting and reducing the room for maneuver of social organizations. Every now and then, one can hear announcements of "taking care" of organizations by introducing vetting and control. ${ }^{177}$ The alerted CSOs deliberated on defense strategies several times. Prominent PiS politicians declared that after gaining control over the courts, it would be time for the private, independent media, then for the CSOs, in that order. ${ }^{178}$

Several developments have already taken place. The National Institute of Freedom-Center for the Development of Civil Society was created to impact the distribution of funds that have been politicized. Grants are often awarded to newly established organizations without prior records and funds are allocated to other objectives than originally planned. ${ }^{179}$ There have also been several attacks on specific organizations and activists, including a public television hate campaign showing alleged suspicious links between activists and organizations. George Soros is also a regular target of the public media.

The objectivity of CSOs that support judges is also being questioned. They are attacked by the ruling camp as "leftist," "traitorous," or "defending the communist past." 180 However, these are primarily organizations independent from politicians that stand up for their missions and keep their distance from party politics. The following example shows it well. Before the parliamentary elections of 2015, the previous Sejm, at the very end of its term, changed the relevant law and elected five judges of the Constitutional Tribunal, including two "in reserve." So, an attempt to pack the CT did not begin with the new government. Furthermore, the CSO, the Helsinki Foundation for Human Rights, was the only entity that openly protested - in the opinion delivered during the parliamentary consultation process - against this unconstitutional move, later confirmed as such by the judgment of the Constitutional Tribunal. Also, the coalition of CSOs, organizations monitoring the

\footnotetext{
${ }^{176}$ See also Łukasz Bojarski, Krajowa Rada Sądownictwa, in Jak przywrócić państwo prawa?, FUNDACJA IM. STEFANA BATOREGO (Tomasz Zalasiński ed. 2019), https:/www.batory.org.pl/wp-content/uploads/2020/02/Jak-przywrocic-panstwoprawa_Interaktywna.pdf.

${ }^{177}$ See, e.g., Magdalena Chrzczonowicz, The Government is Preparing an Attack on NGOs in Poland, RuLE OF LAw (May 12, 2020), https://ruleoflaw.pl/the-government-is-preparing-an-attack-on-ngos-in-poland/; Poland's New Front: A Government's War Against Civil Society, Human Rights First (Aug. 2017), https://www.humanrightsfirst.org/sites/default/files/PolandReport-August-2017.pdf

${ }^{178}$ Krystyna Pawłowicz, who at the time was a Member of Parliament. See Media Freedom Rapid Response, Democracy Declining: Erosion of Media Freedom in Poland, InTERnATIONAL Press Institute (Feb. 11, 2021), https://ipi.media/mfrrreport-erosion-of-media-freedom-gathers-pace-in-poland/.

${ }^{179}$ According to a report by the Supreme Audit Office, money from the Justice Fund that was intended to help victims of crime was used by the Minister of Justice for other objectives, including political—for example, MoJ donated to Firefighters. See Pomoc z Funduszu Pomocy Pokrzywdzonym nie dla pokrzywdzonych, NaJwyższa IzBA Kontroli: Pomagamy w NAPRAWIANIU PAŃSTWA (June 29, 2018), https://www.nik.gov.pl/aktualnosci/fundusz-pomocy-pokrzywdzonym.html.

${ }^{180}$ See Jakub Dymek, Rząd Szydło uderza w organizacje pozarządowe. Wymyślili powód. Papuguja język Putina, gazeta.pl, 31.07.2017, https://wiadomosci.gazeta.pl/wiadomosci/7,114871,22173211,dymek-rzad-szydlo-uderza-w-organizacje-pozarzadowewymyslili.html; Anton Ambroziak, Wirus obcej agentury wraca do Polski. Śladem Putina i Orbana chca „Sorosem” wykończyć organizacje pozarządowe, oko.press, 26.07.2017, https://oko.press/wirus-obcej-agentury-polski-orban-sorosem-chca-wykonczycorganizacje-pozarzadowe/.
} 
elections to the Constitutional Tribunal, protested against the too quick and non-transparent appointment procedure. ${ }^{181}$ At the same time, academia remained silent. ${ }^{182}$

Nevertheless, CSOs are active, defend the courts and judges continuously, and undertake numerous group activities which all prove the considerable solidarity of the community. It ranges from various public statements supported by several dozen organizations to the campaign of civil society candidate for the position of the Ombudsperson supported by approximately 1,200 organizations. $^{183}$

\section{On a Daily Basis-Activities of Citizens and Judges}

Since the elections of 2015 , one has witnessed a great richness and diversity of activities related to judges' resistance or attempts to counteract the backsliding of the rule of law undertaken by both the judiciary and CSOs. Part of their activities have commenced independently. However, part of what they do is collaborative, ranging from the ongoing exchange of information to the joint development of resistance strategies and implementing activities side by side. The framework of this Article does not allow for a detailed presentation and analysis of all the actions undertaken by both groups. Therefore, I focus mainly on the joint activities, showing a diversity of approaches used. It will allow us to see both the role of CSOs vis a vis the judiciary and the role of cooperation between both communities.

When it comes to judges, due to the lack of official judicial representation and spokespersons on the state level, advocacy for judges has been undertaken by judges' associations, informal judges' initiatives, ${ }^{184}$ and through judges' cooperation with CSOs. No judicial association supports the governmental "reform." Associations most active in the judicial resistance have been the Association of Polish Judges Iustitia, which is the oldest and biggest, ${ }^{185}$ and the Association of Judges Themis, ${ }^{186}$ the second general judicial association. There are two specialized associations of family judges, ${ }^{187}$ which both have occasionally joined common initiatives-like statements signed by several judicial associations. Furthermore, the Association of Judges of Administrative Courts was established only in February 2018 as an expression of the willingness of administrative judges to stand up for judicial independence. ${ }^{188}$ It is worth noting that the Lex Super Omnia association of prosecutors has also been formed, boldly standing up for the rule of law and working with judicial associations and other CSOs. ${ }^{189}$

Protests by judges against attempts to limit judicial independence began right after the attack on the judiciary. At first, there were official positions by judges' associations and protests by individual judges. However, the later collective initiatives boosted the morale of the entire professional group. These included the first ever organized ad hoc Extraordinary Congress of Polish Judges-

\footnotetext{
${ }^{181}$ See Małgorzata Szuleka, Marcin Wolny, \& Marcin Szwed, Kryzys Konstytucyjny w Polsce 2015-2016 (2016), at 10-14, https://www.hfhr.pl/wp-content/uploads/2016/09/HFPC-Kryzys-konstytucyjny-w-Polsce-2015-2016.pdf.

${ }^{182}$ And only months later several people, including Professor Andrzej Zoll, former president of the CT, admitted, in response to the author's question, that it was a mistake.

${ }^{183}$ See Zuzanna Rudzińska-Bluszcz: Społeczna Kandydatka Na Rzecznika Praw Obywatelskich, https://naszrzecznik.pl/.

${ }^{184}$ See, e.g., Judges Cooperation Forum, ForUm WsPÓŁPRACY SĘDZIÓw, https://forumfws.eu/fws/.

${ }^{185}$ See STOWARZYSZENiE SęDZIÓw POLSKiCh IUstitia, https://www.iustitia.pl/en/about-us/about-us.

${ }^{186}$ See STOWARZYSZENIE SĘDZIÓw Themis, http://themis-sedziowie.eu/czym-sie-zajmujemy/.

${ }^{187}$ See StOWARZYSZENIE SĘDZIÓw RodZINNYCH w POLSCE, http://www.sssrwp.pl; STOWARZYSZENIE SĘDZIÓw RODZINNYCH Pro FAMILIA, http://sedziowierodzinni.pl/.

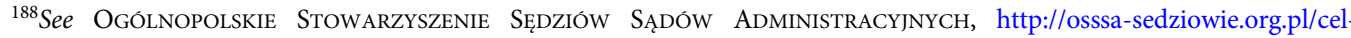
dzialania/. Additionally, there are some small local associations but all together over half of the judges are not members in any association.

${ }^{189}$ See LeX Super OMNIA, http://lexso.org.pl/.
} 
over 1,000 participants - ${ }^{190}$ two large Congresses of Polish Lawyers organized by judges jointly with advocates and legal advisors, ${ }^{191}$ and critical and protesting resolutions adopted by dozens of general assemblies of individual regional and appellate courts. ${ }^{192}$

Thanks to those resolutions, the voices of judicial resistance spread all over the country. Also, they were an expression of the opinion of the vast majority of judges - in the courts' votes - voting against the resolutions were very rare. Finally, some resolutions underlined the role of the civil society. For instance, in the resolution of the General Assembly of the Gorzów Region-totaling forty votes in favor, one against, two abstentions-judges concluded:

The General Assembly of Judges of the Gorzow Region expresses its thanks to all citizens who, together with judges, Polish and foreign legal corporations, non-governmental organizations and the Ombudsman, stand up in defense of the Constitution of the Republic of Poland, the independence of courts and the independence of judges. ${ }^{193}$

The crisis resulting from the government's attack on the courts has also triggered changes. The judicial associations have become more professional and turned into efficient CSOs that respond to challenges hours, seven days a week. Thanks to membership fees, they have their own budget, and they use to a large extent the know-how developed by CSOs over the years. Also, more judges than before engage in different and new activities. Iustitia and Themis are involved in judges' resistance to the extent that this constitutes the vast majority of their activity for the last five years.

The CSOs were supporting mentioned initiatives. In the letter of twelve CSOs to judges gathered at the Extraordinary Congress, one reads:

As representatives of civil-society organizations witnessing the current situation in the judiciary, but first and foremost as citizens, we understand how important it is to keep judges truly independent. We promise to defend them. What we expect from the legislative and executive powers is respect for the judiciary and refraining from any actions which could compromise the independence of the courts and from exerting any pressure on judges. At the same time, we expect judges to stand guard over our constitutional rights and freedoms and act with the moral courage inherent in the truly independent administration of justice .... Good communication between the courts, judges, and citizens is also of crucial importance. We strongly encourage courts and judges to foster such communication and take the initiative to keep society updated about what the courts are doing. ${ }^{194}$

When it comes to civil society, since late 2015, numerous CSOs have devoted a significant part of their activity to the issues of the rule of law and judicial independence. One can divide them into three groups. First, organizations that previously had dealt with human rights and the judiciary, so it was the most natural for them-for example, Amnesty International, HFHR, INPRIS. Second, CSOs that had not dealt with such topics before, but their members felt that they should get involved - the latter were supported by the former, for example, campaigning CSO, Akcja Demokracja. Finally, new organizations and movements that emerged from the wave of protests

\footnotetext{
${ }^{190}$ See Katarzyna Żaczkiewicz-Zborska, Nadzwyczajny Kongres Sędziów Polskich: $w$ obronie państwa prawa i godności [Extraordinary Congress of Polish Judges: In Defense of the State of Law and Dignity], KRAJOWA RADA SĄDOWNICTWA. KWARTALNIK (2016/4).

${ }^{191}$ In Katowice, in May 2017, and in Poznań, in June 2019.

${ }^{192}$ For copies of these documents see IUSTITIA, https://www.iustitia.pl/en/.

${ }^{193}$ See Iustitita, Uchwała Zgromadzenia Ogólnego Sędziów Okręgu Gorzowskiego z dnia 10 września [Resolution of the General Assembly of Judges of the Gorzów District of September 10], IUsTITIA News (Sept. 10, 2018), www.iustitia.pl/ 2506-uchwala-zgromadzenia-ogolnego-sedziow-okregu-gorzowskiego-z-dnia-10-wrzesnia-2018r.

${ }^{194}$ Extraordinary Congress of The POlish Judges (GrZegorz BorkowsKi, ed., 2016), at 103-04.
} 
against the authoritarian tendencies—like Komitet Obrony Demokracji KOD, Obywatele RP_— 195 sometimes solely to defend the courts-like Free Courts and Justice Defense Committee KOS. ${ }^{196}$

It was not always an easy decision debated by the governing bodies and activists. INPRIS illustrated this with the dilemma of "Expert v. Freedom Fighter":

It is one thing for a legal think tank to research the optimal number of assistants per one judge, and it is quite another thing to discuss the government's proposal to fire overnight all the Supreme Court Justices. Both problems require competent, objective analysis. The latter issue is so important, and the solution is so controversial that the think tank staff feels the professional and moral duty to go further than research - experts become "freedom fighters." 197

There are different ways to analyze CSOs' engagement and cooperation with judges after 2015. I suggest two approaches that will capture the subject best: First, looking chronologically, and then focusing on different types of action. When it comes to the chronological look, one may divide citizen involvement in defense of the judiciary in 2015 through 2020 into two main stages, the cutoff date being July 2017 - the time of wide social protests.

The Constitutional Tribunal was the first to be attacked. Beginning at 10:00 PM on November 25, 2015 and ending on November 26, 2015, after the Sejm illegally invalidated the earlier election of Constitutional Tribunal judges, citizens spontaneously organized the first picket in front of the Parliament. The initial picket turned into a series of protests under the slogan "Hands off the Tribunal." 198

CSOs reacted immediately. Eight CSOs and the National Bar Council wrote the first letter to the Venice Commission asking for intervention on December 2, 2015. ${ }^{199}$ Although it was known that they could not formally invite the Commission to Poland, it triggered a discussion, which resulted in the official invitation from the government.

However, it was difficult for CSOs to convince the public to wide protests in defense of the CT. The demonstrations - with a few exceptions — did not gather crowds. The government and public media, which were already politically taken over, brutally attacked the Tribunal, accused it of "leftism," and blocking state reforms. ${ }^{200} \mathrm{CSO}$ - as well as Ombudsperson and private media-initiated educational campaigns on the role of the CT in the state system and the life of individual citizens. So, for instance, during demonstrations, CSO's volunteers answered questions about the CT, its jurisprudence, and its role in the state- "human library" type of project. It turned out that for many years the CT itself did not build recognizability and broad social trust due to its hermetic nature and lack of communication with citizens. Moreover, it had been urged to do so by CSOs many years earlier. ${ }^{201}$

\footnotetext{
${ }^{195}$ See Komitet Obrony DemoKracj, https://ruchkod.pl; ObYwatele RP, https://obywatelerp.org.

${ }^{196}$ See Wolne SĄDY, https://wolnesady.org; See also Komitet OBrony SprawiedliwoścI, https:// komitetobronysprawiedliwosci.pl/.

${ }^{197}$ Institute for Law \& Society INPRIS, How Legal Think Tanks Provide, or Fail to Provide, Knowledge to Governments in Central and Eastern Europe. policy paper (2017); Legal Think Tanks and GovernmentCAPACITY BUILDING. REPORT (ŁUKASZ BOJARSKi \& FILIP WEJMAN, eds., 2017).

${ }^{198}$ Ręce precz od Trybunału [Hands off the Tribunal]. See Łukasz Bojarski, Patrzymy na Was [We Are Looking at You], in: Prawnik, Dziennik Gazeta Prawna at D6-7 (Nov. 22, 2016).

${ }^{199}$ See Joint Letter from the Helsinki Foundation for Human Rights, Polish Bar Council,Institute of Law and Society INPRIS, Center for Citizen Education, Institute of Public Affairs, Panopytkon Foundation, Stefan Batory Foundation, Civil Development Forum, and Citizens Network Watchdog Poland, to The Venice Commission, (Dec. 2, 2015), https:// www.hfhr.pl/wp-content/uploads/2015/11/HFHR_venice_comission_2122015.pdf.

${ }^{200}$ Notwithstanding the fact that Polish Constitutional Tribunal was rather conservative, at least in its jurisprudence on issues such as abortion or the place of church and religion in a state.

${ }^{201}$ See Dawid SzeŚciŁo, TrybunaŁ Konstytucyjny: Informacja, KomunikaCja, Wizerunek [Consitutional Tribunal: Information, Communication, Image] (INPRIS, 2010).
} 
For over a year, CSOs supported the Constitutional Tribunal in various ways while it was under attack. They did so by calling people to demonstrate and picketing and publicizing the problem in the international arena, publishing legal opinions, appearing in proceedings before the CT as amicus curiae, and organizing debates in which the judges of the Tribunal were suggested various defense strategies. ${ }^{202}$ Unfortunately, the number of citizens interested in defending the Constitutional Tribunal was not significant, and Constitutional Tribunal judges were reluctant to undertake the strategies advised-in contrast to the later developments regarding Supreme Court. ${ }^{203}$

The National Council of the Judiciary was the second institution attacked throughout 2016 and 2017. Because there was no communication strategy in the past, citizens knew even less about the National Council of the Judiciary than the Constitutional Tribunal. ${ }^{204}$ Society began to undergo accelerated education. First, due to a sharp critique of the NCJ by the government and supporting media. And second, due to activities of defenders of an independent judiciary, including the NCJ itself, judges' associations, the legal professions, and CSOs. Through numerous activities, organizations tried to make citizens aware of the importance of the National Council on the Judiciary.

The Supreme Court and the ordinary courts became the target of the third attack, which was called by some, and rightly so, a constitutional coup d'état. ${ }^{205}$ On July 12, 2017, the Parliament finally passed new acts on Ordinary Courts and the NCJ. Only then, the same day at 23:30, the draft law on the Supreme Court appeared on the Parliament's website-a document of 130 pages. This draft act, de facto liquidating the existing Supreme Court, was not known before, including to the state organs, and was not consulted. Although developed in the Ministry of Justice, it was submitted to the Parliament by a group of Members of Parliament to bypass mandatory consultations. ${ }^{206}$ The Sejm passed the law immediately-three readings in three days-and went on vacation. The Senate approved it on July 22, 2017, at 2 a.m., including bizarre errors that the authorities must have been aware of. ${ }^{207}$

Despite the vacation time and the rapid legislative procedure, building a defense strategy started on the first night from July 12, 2017, to July 13, 2017. A couple of days later, on July 16, 2017, two organizations, the judges' association Iustitia and Citizens' Action Democracy, ${ }^{208}$ organized a protest in front of the Supreme Court in Warsaw that will go down in history. This first protest, "Chain of Lights," grew into hundreds of local protests in front of the court buildings, grouping thousands of people throughout Poland for several days. On the SC building, citizens displayed the inscription, "This is our court." ${ }^{209}$ During protests, the President of Poland vetoed bills on the NCJ and SC but still signed the bill on the ordinary courts. Amended bills on the SC and the NCJ were passed several months later.

So, if compared with the CT, the case of the Supreme Court was different. Hundreds of thousands of people defended the SC from dissolution. But, it was only the beginning, and further engagement followed. Below, I list additional activities undertaken by CSOs to support judges of the SC, to inspire them and mobilize them to defend the court's independence.

\footnotetext{
${ }^{202}$ Interestingly, public awareness of the Constitutional Tribunal's role rose instantly only at the end of 2020, due to the ruling banning terminations of pregnancies with fetal defects as unconstitutional. The verdict sparked enormous protests and also made many people aware of the role that CT can play in their lives. See Ewa Łętowska, A Tragic Constitutional Court Judgment on Abortion, Verfassungsblog.DE (Nov. 12, 2020), https://verfassungsblog.de/a-tragic-constitutional-courtjudgment-on-abortion/.

${ }^{203}$ It is a very interesting subject for future studies and analyses of a different kind, not just legal but also sociological and psychological.

${ }^{204}$ It is also often mistaken with the public court register due to the same acronyms of both institutions: KRS.

${ }^{205} \mathrm{~A}$ phrase used, for example, in WojCIECH SAdurSki, Poland's Constitutional Breakdown (2019).

${ }^{206}$ This is a regular government strategy of falsely submitting government bills and bypassing obligatory consultations.

${ }^{207}$ But, they chose not to correct them because then the bill would have to go back to the Sejm, which was already on vacation.

${ }^{208}$ Akcja Demokracja after some consultations with other CSOs, decided to engage in the defense of the courts, a topic previously not covered by them. AKCJA DEMOKRACJA, https://www.akcjademokracja.pl/.

${ }^{209}$ To jest nasz Sąd [This is Our Court].
} 
Determining the individual causes of specific events and behaviors of Supreme Court judges is very difficult and would require major sociological studies. However, thanks to participatory observation, it can be concluded with high confidence that the role of CSOs in initiating and sustaining the SC resistance was crucial. It also seems that after the "opening" the CSOs helped create, judges started to take increasing action on their own initiative. ${ }^{210}$

On the wave of the July protests, the Free Courts initiative, Wolne Sądy, was founded by four lawyers - three advocates and a CSO activist. While it was conceived as an initiative that brings public awareness to the role of the courts - through interviews and clips of famous people and celebrities who tell short stories showing the importance of judicial independence,-it has developed into a significant enterprise. ${ }^{211}$

The entry into force of bills on SC, on the NCJ, and on ordinary courts triggered another critical initiative-the Justice Defense Committee (KOS) was established on June 4, 2018, by eight organizations. $^{212}$ According to KOS, the three laws mentioned threatened the independence of courts and judges and thus, also the independence of other legal professions, including advocates, legal advisors, and prosecutors. KOS declared defending the independence of judges and the legal profession and assisting those targeted and under pressure. Since June 2018, KOS became the central platform of cooperation between CSOs and judicial associations.

Before establishing the KOS and in subsequent years, the involvement of CSOs and their work with judges has been characterized by a wide variety of activities. I am describing below events and developments that, in part, are still ongoing, ${ }^{213}$ and some of which are non-public in nature. The following catalog of activities and approaches used is therefore illustrative and not exhaustive. It aims to show diversity and richness but also signalize the importance of the CSOs' involvement.

Building a strategy for defenders of the rule of law is something that CSOs are committed to. Regardless of the plans of individual organizations, a common strategy is established through cooperation platforms, such as KOS. The whole legal complex-judges, prosecutors, attorneys, and CSOs-meet regularly, discuss and decide on strategy, but also, thanks to modern technologies and social media, stay in touch for twenty-four hours, seven days a week. Obviously, state authorities have incomparably bigger human, organizational, and financial resources at their disposal. However, much more limited social resources, thanks to joint planning and sharing of tasks, allow the social side to complement and avoid duplicating, exchange all relevant information on an ongoing basis, assist each other, and plan joint activities.

Monitoring and archiving legal developments and cases of exerting political pressure on judges, prosecutors, and attorneys were some of the original objectives of the KOS. However, several initiatives try to accomplish this. Apart from the "Archive of Repression"214 run by KOS or the archive of Iustitia, special initiatives have been set up. The "Wiktor Osiatyński Archive" collects information, creates a calendarial of resistance, and-together with Forum Obywatelskiego Rozwoju and Helsinki Foundation for Human RIghts runs ruleoflaw.pl portal in English.

\footnotetext{
${ }^{210}$ Both, when it comes to the formulation of preliminary questions and all sorts of resolutions by various Supreme Court panels.

${ }^{211}$ All four founders are acting within different initiatives, mainly the Justice Defense Committee-KOS. They were acknowledged and rewarded on numerous occasions. Moreover, Wojciech Sadurski acknowledges them in SADURSKI, supra note 205.

${ }^{212}$ Komitet Obrony Sprawiedliwości KOS [Justice Defense Committee] was created by: Amnesty International, the Helsinki Foundation for Human Rights, InSTITUTE FOR LAW \& SOCIETY INPRIS, the Professor Zbigniew Holda Association, judges' associations Iustitia and Themis, prosecutors' association Lex Super Omnia, and the Professor Osiatyński Archive. Five more organizations joined later-as of June 2021. See Komitet Obrony Sprawiedliwości [Justice Defense Committee], https:// komitetobronysprawiedliwosci.pl/.

${ }^{213}$ The final version of the Article was drafted in June, 2021.

${ }^{214}$ See Archiwum Represji [Archive of Repression], Komitet Obrony SpRawiedliwości [Justice Defense CommitTeE], https://komitetobronysprawiedliwosci.pl/archiwum-represji/.
} 
Assistance offered to individuals who are either the targets or victims of the attacks or victims of the pressure put on them is the crucial element of the support organized by CSOs. The premise of the cooperation between judges and CSOs is that anyone who needs help should get it. This has two dimensions, helping the individual person, but also counteracting the tactics of state agencies and public media based on creating a chilling effect. The idea behind the support is that everyone involved in judicial resistance should know that they will be cared for if they need it.

Legal assistance and representation provided by attorneys cooperating with KOS for judges and prosecutors under attack is a flag activity. Numerous attorneys-both those with a record of previous cooperation with CSOs and new ones-handle pro bono cases of judges accused before disciplinary bodies and judges facing their immunity being stripped to be presented with criminal charges. This includes also representing judges in administrative, civil, or labor cases, for instance, in proceedings involving the unjustified transfer or forced retirement of judges. ${ }^{215}$ Moreover, attorneys often work hand in hand with judges also representing their colleagues.

Psychological assistance is an example of other individual assistance provided. KOS has developed a unique system for providing this kind of support to judges and lawyers in cooperation with the psychological and therapeutic communities. ${ }^{216}$ In Poland, it is still taboo for lawyers to seek psychiatric or psychological assistance. ${ }^{217} \mathrm{KOS}$ has created communication channels that make it easier for lawyers and victims of political mobbing to get professional help. ${ }^{218}$

Moral support is another form of help for those judges and lawyers who are treated as enemies by the authorities and those who are targets of hate campaigns and constant harassment. It may manifest itself in various ways, like individual contacts and support, demonstrations and letters of support in defense of concrete judges, and organized public support to counteract often disgusting personal attacks on judges. So, for example, when a particular judge, sometimes not previously known to the public, from a small local court is attacked for political reasons-for instance, for a ruling they delivered-he or she is met with expressions of sympathy and support from wellknown people, the so-called legal authorities_- "big names." And not just through the media; it is not done in public. Such people are given the judges' contact information and may reach them by phone or letter. Support from these well-known and respected people is of importance to judges under attack. ${ }^{219}$

Involving judges into various CSOs' activities is another method. An excellent example of involving judges suspended from office for political reasons in CSO projects is the Tour de Constitution education campaign that started in the summer of 2021. Judges and CSO activists travel around the country and educate about civil rights and civil liberties. ${ }^{220}$

Strategic litigation ("test cases" or "impact cases") constitutes a significant portion of the cases handled by the attorneys cooperating with CSOs within KOS. These precedent-setting cases take place before both national courts and international tribunals. High profile, internationally discussed decisions and Polish judgments of the Court of Justice of the European Union (CJEU) and ECtHR result from preliminary questions asked by national courts and complaints from citizens or the European Commission. But behind almost every such question, complaint, and ruling, there is an enormous amount of effort to prepare and handle the case by lawyers from CSOs.

\footnotetext{
${ }^{215}$ See Komitet Obrony Sprawiedliwości [Justice Defense Committee], Państwo, które karze—Raport Komitetu Obrony Sprawiedliwości [The State that Punishes-Justice Defense Committee Report] (2019), https://komitetobronysprawiedliwosci. $\mathrm{pl}$ /panstwo-ktore-karze-raport-komitetu-obrony-sprawiedliwosci-kos/ (describing over fifty cases of judges and prosecutors).

${ }^{216}$ See Komitet Obrony Sprawiedliwości, Pomoc Psychologiczna dla Prawników. Pakiet Informacyjny "Prawnik Pod Presją" [Psychological Assistance for Lawyers. Information Package "Lawyer Under Pressure"], https://komitetobronysprawiedliwosci. pl/app/uploads/2019/05/ulotka-KOS_psycholodzy.jpg.

${ }^{217}$ See Ewa Woydyło, W Imię Temidy [In the Name of Themis], Krajowa Rada SĄDOWnictwa. KWARTALNIK (2016/1).

${ }^{218}$ See Łukasz Bojarski, Powalczmy o Sędziów, Nie Tylko o Sądy [Let's Fight for Courts, Not Only for Judges], PRAWNIK, Dziennik Gazeta Prawna at D4-5 (July 10, 2018).

${ }^{219}$ Information received by the author during private conversations with judges.

${ }^{220}$ See Tour De Konstytucja [Tour of THE COnstiution], https://www.tour-de-konstytucja.pl/.
} 
These are elements largely covered by the secrecy of the "legal kitchen," which, for various reasons, including tactical ones, the public is not kept informed. However, those familiar with the strategic litigation approach know the resources required to initiate and pursue such cases. ${ }^{221}$

Boycotting, naming, and shaming are methods used by CSOs to expose illegal state procedures. For example, Akcja Demokracja (AD), Obywatele RP, and other CSOs were publicly calling, in line with judicial associations, for boycotts of the illegal elections to the NCJ. Organizations also use "naming and shaming" methods-for instance, Akcja Demokracja published the names of the candidates who applied to the NCJ despite the boycott on street billboards (AD collects money for such campaigns from citizens). ${ }^{22}$ CSOs had also picketed and blocked the seat of the NCJ. And even though the judicial members of the NCJ were replaced, only eighteen out of 10,000 judges applied for those seats - experts and media quickly linked almost all of them to the Minister of Justice. ${ }^{223}$ Other ways of shaming judges, who have become "officials of the regime," include publicly stigmatizing them either in publications, ignoring them, or not shaking their hands-which is a tradition in Poland when greeting somebody. ${ }^{224}$

Providing information for the public about the rule of law backsliding and about concrete cases of putting pressure on judges, prosecutors, and lawyers is another critical measure. In cooperation with judges, CSOs develop different information strategies on actions undertaken and numerous press releases, positions, and appeals. For example, the KOS has held dozens of press conferences since June of 2018 to counterbalance state media releases and communicate the truth to the public.

Educational activities have both, short-term and long-term objectives. Interestingly, one can argue that the dynamics of social protests in defense of the courts, presented above, have shown previous educational and communication negligence. This gap inspired authors of a new projects. For example, Professor Zbigniew Hołda's Association runs twice a year aConstitutional Week, where hundreds of lawyers conduct workshops on the Constitution for thousands of students in schools. ${ }^{225}$ Moreover, the already mentioned new project, Tour de Constitution, commenced. Both projects are also exampling the cooperation of CSOs with judges. However, the number of educational activities that emerged from the crisis is much more significant.

Advocacy and intermediation in the involvement of institutions, politicians, academics, and media is another important way CSOs work for, or in cooperation with, judges. These include numerous contacts, constant information exchange, meetings with representatives of national and international institutions and organizations, and politicians, academics, and the media. Only part of these undertakings is made public. Some of the activities commenced by representatives of these institutions are inspired and sometimes partly organized by CSOs. For example, the translation and transmission of important documents like the Polish Prime Minister's motion to the Constitutional Tribunal to verify the constitutionality of the EU Treaties-driven by judicial matters - undertaken by KOS, allowed for quick familiarization of foreigners with this document and the preparation of numerous statements and articles, including scientific ones, on this

\footnotetext{
${ }^{221}$ See a book chapter written by two advocates describing their work on the CJEU cases on behalf of The Judicial Defense Committee: Sylwia Gregorczyk-Abram \& Michał Wawrykiewicz, Terra incognita. postępowania indywidualne w obronie sędziów Sądu Najwyższego i Naczelnego Sądu Administracyjnego. Tematyka pytań prejudycjalnych [Terra Incognita. Individual Proceedings in Defense of Judges of the Supreme Court and the Supreme Administrative Court. The Subject of the Questions Referred for a Preliminary Ruling], in KonstyTUCJA, PRAWORZĄDNOŚć, WłADZA SĄDOWNICZA: AKTUALNE PROBLEMY TRZECIEJ WŁADZY W POLSCE [The Constitution, the Rule of Law, the Judicial Authority: Current Problems of the Third Authority in Poland] (Łukasz Bojarski, Krzysztof Grajewski Jan Kremer, Gabriela Ott \& Waldemar Żurek eds., 2019).

${ }^{222}$ See Akcja Demokracja, Nie Kandydujcie! Apel do Sędziów [Do Not Run! Appeal to Judges], https://dzialaj. akcjademokracja.pl/campaigns/323.

${ }^{223}$ See Łukasz Bojarski, 15 kolegów wiceministra, czyli o reformie KRS [15 Colleagues of the Deputy Minister, i.e. on the Reform of the National Council of the Judiciary], Prawnik, Dziennik Gazeta Prawna at D4-5 (Apr. 18, 2017).

${ }^{224}$ See Łukasz Bojarski, Bon ton sądowy i trybunalski [Bon Ton in a Court and Tribunal], PRAWNIK, DZIENNIK GAZETA PRAWNA at D4-5 (Nov. 5, 2019).

${ }^{225}$ See Tydzień Konstytucyjny, STOWARZYszenie IM. Prof. ZBIGnIEWA HOŁDY, http://stowarzyszenieholda.pl/projekty/ tydzien-konstytucyjny/.
} 
topic. $^{226}$ In July 2018, in Warsaw, crowds of people were defending the Supreme Court and its president, whom the government wanted to retire. At the same time, in Strasbourg, activists from ObywateleRP were handing out leaflets about the situation of Polish courts to Members of European Parliament.

Calling judges to action, asking, sometimes "demanding," persuading, and trying to convince judges to behave in a particular manner is another way of acting. The situation over the SC is a good example. In the opinion of CSO activists expressed in publications, positions, and private communications, judges should more actively resist.

First, judges should undertake legal actions in response to state actions, especially legal precedent strategies, including asking preliminary questions. As paradoxical as it sounds, CSO activists are more experienced in strategic litigation than judges. Moreover, judges are not accustomed to bringing cases about themselves.

Second, judges should communicate with the public and inform the public about the reasons for their decisions - for example, why they are leaving the job in a court, why they are resigning, or why they are not resigning and resisting forced retirement. The situation around the SC was so unclear that even educated lawyers found it difficult to follow, not to mention the general public. Only intensive efforts by CSOs, including convincing judges of their obligation to communicate their decisions to citizens, began to yield some partial results. Some judges, including the SC president, began to come out to protesting citizens, and some judges began to explain their decisions to citizens in writing. ${ }^{27}$

Finally, judges should not abdicate and leave the court, despite the political attack on them and the documents on which their departure was allegedly based. Akcja Demokracja organized a campaign of sending postcards to judges asking them to keep their posts. For several weeks, members of the ObywateleRP greeted incoming judges in front of the SC with a large "Stay" banner. ${ }^{228}$ These actions caused some of the judges who previously wanted to resign-also in a gesture against the governmental policy-to remain in the office. In the public debate, opinions were expressed that the judges should not leave the citizens alone and, instead, should stay in their positions to defend the court and thus defend the rights of citizens. ${ }^{229}$

\section{Continuity and Discontinuity}

Generally, after 2015 and especially after July 2017, the cooperation of CSOs with judges-individually and groups of judges - and with judges' associations developed and deepened. Before 2015, we talked about thematic relations or cooperation and the implementation of specific projects. Since late 2015, this cooperation has been limited mainly to communication between judges and citizens, related educational activities, and, above all, activities defined as defense of

\footnotetext{
${ }^{226}$ Rule of Law, PM Action to Review Constitutionality of EU Treaty Now in English, Rule OF LAw: EsSENTIAL READINGS (May 20, 2021), https://ruleoflaw.pl/pm-action-to-review-constitutionality-of-eu-treaty-now-in-english/.

${ }^{227}$ For example, Supreme Court Justice Dorota Rysińska, who took the opportunity to retire early, justified her decision in a letter with the intention of passing this information on to citizens. See Letter from Dorota Rysińska, Supreme Court Justice, to the Public (May 9, 2018), źwww.sn.pl/aktualnosci/SiteAssets/Lists/Wydarzenia/NewForm/Odpowiedź\%20na\%20listy.pdf. Judge Rysińska also made a statement regarding the rejection of additional money paid to her, which was intended to be an incentive for judges to leave the Supreme Court. See Marek Adamski, Była sędzia SN Dorota Rysinska: wynagrodzenie w przewidzianej nowelizacja wysokości nie jest mi należne [Former judge of the Supreme Court, Dorota Rysińska: The Remuneration in the Amount Provided for by the Amendment is Not Due to Me], RzeczPospolita: SAdDy i TrybunaŁy (Jan. 10, 2019), http://www.rp.pl/. Justice Stanisław Zabłocki, president of the Supreme Court's Criminal Chamber, is another good example. He communicated his decisions through social media several times, including those regarding his abdication, explaining his motivations and moral choices.

${ }^{228}$ Wojciech Fusek, Zostańcie! Wspieramy Sędziów Sądu Najwyższego [Stay! We Support the Judges of the Supreme Court], ObYwatele RP: AKTUALności (Sept. 12, 2018), https://obywatelerp.org/zostancie-wspieramy-sedziow-sadu-najwyzszego/.

${ }^{229}$ See Łukasz Bojarski, Sędziowie, Liczymy na Was [Judges, We Are Counting on You], PRAWNiK, DzIENNIK GAZETA PrAWNA at D2-3 (Jan. 23, 2018).
} 
democracy, defense of the rule of law, and defense of the independence of courts and judges. The number of other initiatives concerning the courts' reform and improvement of their work decreased significantly.

The good relations of CSOs with the Constitutional Tribunal after December 2016-the end of the term of Constitutional Tribunal president Andrzej Rzepliński-and the National Council of the Judiciary after April 2018-establishment of a new Council-has almost disappeared. The majority of the legal circles no longer treat those organs as if they are in line with the Constitution and, to emphasize this fact, call them quasi-organs, de facto tools in the hands of politicians. ${ }^{230}$ As for relations with the Supreme Court, they were strong until the end of the term of office of its President, Małgorzata Gersdorf in April 2020. They have been limited since.

The interaction of CSOs with the judiciary at the level of ordinary courts has been also limited due to the crisis. Until 2015, court presidents made decisions about cooperation with organizations independently. But, because many of them have been dismissed due to termination of the term of office, the new presidents who are appointed by the minister of justice, are often seen as political representatives of the government and no longer independent. Additionally, the COVID-19 pandemic compounded the constitutional crisis. Periodic lockdowns and limited access to courts almost eliminated other activities besides those focused on the defense of judicial independence.

However, at the same time, the previous pre-2015 experience of building mutual trust and relations between judicial associations and CSOs seemed to bring fruits in the time of the rule of law backsliding. The cooperation of judges with CSOs and social movements has never been as intense and continuous as from 2015. But it has changed its character when compared to the past. Let us have a look at the elements of discontinuity in this respect.

\section{Communication or Isolation}

There was almost no civil society in the People's Republic of Poland, and everything that was individual, grass-roots, or initiated by people was suspect in advance. The lack of knowledge on the role of CSOs in a democracy and lack of relevant experience resulted in a lack of trust in civic initiatives. Despite the experience of Solidarność and the transition of 1989, this approach persisted for an exceptionally long time - and some of it still does. According to this approach, the court should be isolated and the judge should limit him or herself to adjudication in the courtroom and without leaving. Additionally, judges were averse to anyone who looked at the "judges' hands." What continues is their oversensitivity and lack of proper balance between being independent and accountable. However, as already noted, this approach is changing, and especially in the time of the rule of law backsliding, more and more judges are convinced that they should communicate with citizens. It is well illustrated in the recent article coauthored by former president of the Supreme Court, professor Małgorzata Gersdorf, which reads:

The main thesis of this contribution is that it is not in every country and under every political circumstance that the form of judges' participation in public discourse can be limited to only typical judicial activities. The democratic crisis in Poland reveals a dramatic need for judges as educators and members of society to be active also outside the courtroom. ${ }^{231}$

In the event of an attack on the courts, the same persons who had been reluctant to cooperate with CSOs, be it judges, members of the NCJ, or the SC's president, were more open to the activities of organizations in defense of the courts. But do they recognize their efforts? Not all. In the recent

\footnotetext{
${ }^{230}$ See Marcin Matczak, The Clash of Powers in Poland's Rule of Law Crisis: Tools of Attack and Self-Defense, 12 HaGUE J. Rule L. (2020).

${ }^{231}$ Małgorzata Gersdorf \& Mateusz Pilich, Judges and Representatives of the People: A Polish Perspective, 16 EUR. CONST. L. REV. 345 (2020). At 6.
} 
article coauthored by Małgorzata Gersdorf, authors underline the extraordinary situation in Poland but do not mention CSOs in this context:

The example of Poland, compared to other countries that have happened to undergo severe democratic crises, is unusual, as it shows the radical and widespread disagreement and resistance of legal circles to the destruction of structures of the democratic state ruled by law. Significantly, the voice of protest comes from within the Polish judiciary - it is the voice of the judges themselves, and mainly of those of the common courts, as they are under the greatest pressure to subordinate themselves completely to political authorities. ${ }^{232}$

Interestingly, authors de facto repeat and internalize CSOs recommendations voiced for years, still not mentioning their role: ${ }^{233}$

We appreciate the fact that in the last five years our own awareness of the role of judges in society and their responsibility for the fate of the state has changed radically. Judges have become visible outside the courts. ${ }^{234}$

\section{Legal Complex}

During the Solidarność era, the communities of advocates and legal advisors were trying to become professionals independent from the state. They worked on relevant draft laws ${ }^{235}$ and met during the groundbreaking National Congress that adopted numerous resolutions, including those related to judges, their status, and warranties of judicial independence. ${ }^{236}$ Judges, lawyers, and legal academics cooperated in the Center for Civic Legislative Initiatives of Solidarność and its Social Legislative Council, which was created in January 1981 in Krakow and headed by the rector of the Jagiellonian University. From 1981 to 1992, the Center developed several dozen draft bills, involving around one hundred experts and two hundred collaborators. ${ }^{237}$ These included essential drafts related to the judiciary.

Looking from the perspective of the legal complex, one can also notice certain continuations in the involvement of lawyers and academics in CSO activities. For example, according to Grzegorz Waligóra, in the 1970s, the program, documents and public positions of KOR and ROPCiO were, especially in the initial period, prepared by lawyers in order to weigh words and not to facilitate retaliation by the authorities. ${ }^{238}$ Additionally, the participation of scholars, including but not limited to legal scholars, among freedom fighters was and is a hallmark of Polish social movements.

When it comes to the involvement of CSOs in the legal complex, what helps in its development is the engagement in $\mathrm{CSOs}^{\text {c }}$ work of those who play other professional roles. Some persons, for instance, have come to a path from engagement in CSOs and academia to becoming judges. Professor Andrzej Rzepliński was engaged in the work on social draft laws from the 1980s. Later, he worked at the Helsinki Foundation for Human Rights management board for years, initiating and overseeing legal programs, including those focused on the judiciary. After 2015, already as a judge and a president, he became a symbolic defender of the CT. Professor

\footnotetext{
${ }^{232} I d$, at 3 .

${ }^{233}$ However, in some footnotes of the paper authors refer to the publications prepared by CSOs.

${ }^{234}$ See Gersdorf, supra note 231, at 29.

${ }^{235}$ Paradoxically both Acts, on the Bar and on the Legal Advisors, prepared during the Solidarnośc era, were passed by the Parliament during the martial law state in 1982.

${ }^{236}$ Ogólnopolski Zjazd Adwokatury [National Congress of the Bar], Jan. 3-4, 1981, Poznań.

${ }^{237}$ See Barczyk, supra note 59.

${ }^{238}$ See Grzegorz Waligóra, Uwagi do artykułu Jana Skórzyńskiego "Apel do społeczeństwa polskiego" i Geneza ROPCiO [Comments to Jan Skórzyński's article "Appeal to Polish Society" and the Genesis of the ROPCiO], 16 Pamięć i Sprawiedliwość 539, 541-42 (2010).
} 
Marek Safjan, a member of the Polish Helsinki Committee, first became the judge and president of the CT and later, the judge of the CJEU. Both Rzepliński and Safjan have been vocal during the rule of law backsliding crisis.

Finally, many people on both sides (the courts and CSOs) began working together well before 2015 and continued in changed circumstances after 2015. All mentioned common projects and different initiatives created before, that included elements of collaboration among legal professions, helped to facilitate today's interactions. For example, the already mentioned Professor Zbigniew Hołda Association, founded in 2010, brings together over one hundred lawyers of all professions and is an excellent platform for brainstorming, discussing, and organizing legal assistance for the lawyers attacked. It is a kind of legal complex in miniature. ${ }^{239}$

\section{Symbolic and Personal Aspect}

Relating to the past, as presented in the previous parts of the Article, let us try to answer the question of where does the CSOs' commitment to the defense of the courts come from? Was it surprising, unexpected, or can we talk about the continuation of certain phenomena, institutions, and behaviors?

The founders of KOS themselves symbolically refer to the past. The name KOS (Justice Defence Committee)intentionally relates to the KOR (Workers Defence Committee) that operated in the 1970s. Additionally, the establishment of KOS was purposefully announced on June 4, 2018, during the celebration of the anniversary of the first-semi-free elections in Poland in 1989. This date is treated by vast political forces as a beginning of the free Republic, while it is disregarded by current governing parties. ${ }^{240}$

Those involved in the underground activities in the 1970s and 1980s very often remained active in the public sphere in subsequent years. It is worth mentioning at least a few people. Danuta Przywara was active in the underground Polish Helsinki Committee from 1982 through 1989, co-founded and co-led the HFHR from 1990 to 2015, and was the founder and member of KOS from 2016 through 2020. For thirty-nine years, she has been associated with organizations whose activities are continuous and she sees certain similarities between the 1980s and the present challenges, although, "it concerns the object of action and the direction in which the 'deforms' we are fighting against are heading, not - at least for the time being — the conditions in which we operate."241

In turn, Marek Antoni Nowicki, one of the pillars of the underground Polish Helsinki Committee, does not see any noteworthy similarities between his activities in the underground of the communist state and the present situation, or a clear line linking of the activities of the Helsinki Committee then and Judicial Defense Committee today. Instead, he draws attention to the Polish fighting gene or freedom gene, which comes to the fore in successive generations fighting for freedom, whether during the partitions of Poland in the 19th century, during the First and the Second World Wars, the Polish People's Republic, and nowadays. ${ }^{242}$

But those active in the underground Helsinki Committee in the 1980s can also be found on the other side of the current dispute, like Jarosław Kaczyński, co-founder of the HFHR, leader of the ruling party $\mathrm{PiS}$ and gray eminence behind governments since $2015 .{ }^{243}$ Other examples include co-founders of the KOR, like Antoni Macierewicz or Piotr Naimski, who are currently influential politicians of the governing party.

\footnotetext{
${ }^{239}$ See StowarzTSZenie Im Prof. ZBigniewa HoŁdy, http://stowarzyszenieholda.pl.

${ }^{240}$ It can be mentioned that in the 1980s there was also the organization KOS (Committee of Social Resistance), which turned out to be an important periodical, with—since 1983-a column devoted to activities of the Helsinki Committee. See Pleskot. 2017, at 12.

${ }^{241}$ Interview with Danuta Przywara, President of the Board, Helsinki Foundation for Human Rights (Dec. 2020).

${ }^{242}$ Interview with Marek Antoni Nowicki (Dec. 2020).

${ }^{243}$ Pleskot notes that Jarosław Kaczyński decided not to give an interview to the author of the monograph on the Helsinki Committee published in 2017. See PlESKOT, supra note 24, at 13.
} 
In fact, many people who remember the times before 1989 point out the remarkable similarities of the current situation with the Polish People's Republic (PRL) period. ${ }^{244}$ However, this can hardly be called a continuation. It is rather a return. The question is how conscious it is to the solutions of that period. And while it is hard to deny the similarities-for example, the increased role of the Minister of Justice and the diminished role of judicial self-governmenttaken as a whole, we are dealing with entirely different realities. And both judges and CSOs are proving it daily. Their activities on this scale would not be possible in the peoples' republic.

\section{Activities}

When looking at the historical periods under our scrutiny, the apparent similarities are worth noting, even if they were coincidental. The current activities of CSOs have many features in common with the activities of the underground Polish Helsinki Committee, despite the entirely different political situation. The Polish Helsinki Committee operated both nationally and internationally, and it was visible in many activities of the Committee, from statements and positions, through publishing activities, to a network of contacts and associates. ${ }^{245}$ The Committee was established to prepare a shadow report for the Madrid Conference. Current CSO activities are similar. One of their first actions was a letter sent to the Venice Commission. KOS and other CSOs are also very active on international forums. In the current statements of CSOs, one can find similar sentences to those that appeared, for example, in the introduction to the first Polish Helsinki Committee report published in 1982, which reads:

We are convinced that the disclosure of abuses and offenses against human rights is the duty and right of all who have reliable information on this subject. Moreover, we think that even these limited resources at the disposal of international bodies may contribute to the improvement of the human rights situation in our country. ${ }^{246}$

The 1982 Madrid Report played a difficult to define role in creating a special resolution condemning repressions in Poland, which was adopted in late spring 1983 by the UN Human Rights Commission at the request of the Netherlands with the support of France, Germany, and Great Britain. ${ }^{247}$ Similarly, documents prepared by CSOs nowadays influence the positions taken by different international institutions, which are currently numerous. And similarly-also anecdotal—nowadays, the Netherlands is one of the leading states engaging in defense of the rule of law in Poland. ${ }^{248}$ Also, quite paradoxically, like during the communist past, the authors of current statements and motions addressed to institutions outside of Poland are called by a ruling majority and dependent media as "traitors"-notwithstanding that they also address organizations Poland is a member too, like Council of Europe or the EU.

Another track is to see continuities in civil society activities, especially during the Solidarity era and today. The differences are apparent. The era of Solidarność, which was a 10-million-strong mass movement, lasted fifteen months. The judges' resistance to the attack on the courts is now in its sixth year and is on a completely different scale. But, there are many common references, and they concern the pursuit of a proper separation of powers and the guarantee of the right to an independent judiciary.

\footnotetext{
${ }^{244}$ See EWA Siedlecka, SęDZIOWIE MÓWIĄ [Judges Speak] (2018) (describing a number of similarities mentioned by interviewees).

${ }^{245}$ See PLESKOT, supra note 24 , at 8.

${ }^{246} I d$. at 35 .

${ }^{247} I d$. at 49

${ }^{248}$ Dutch MPs Urge Cabinet to Take Poland to EU Court for Legal System Interference, DuTCHNEWs.NL (Dec. 2, 2020), https:// www.dutchnews.nl/news/2020/12/dutch-mps-urge-cabinet-to-take-poland-to-eu-court-for-legal-system-interference/.
} 
Other similarities include building a network of enthusiastic and dedicated activists and collaborators who support the cause, including, for instance, pro bono interpreters who translate hundreds of pages of documents. This was the case of the movements in the 1970s and $1980 \mathrm{~s},{ }^{249}$ and it is the reality of the work of KOS.

Unexpectedly, one of the similarities is the secrecy of the operation. In the 1980s, it stemmed from the threat of arrest. Nowadays, organizations and judges do not undertake illegal activities. However, the nature of some of those actions makes them not public — it is, for example, about planning strategies to counteract the adverse effects of changes introduced by the government, like strategic litigation.

But, if we move from the times of the Peoples Republic and compare the post-1989 period with the post-2015 events, the continuation is visible and direct. What has developed before, like relations of judicial associations with CSOs and numerous contacts among judges and activists, might be noticed later in mutual trust and cooperation in recent years. What did not work satisfactorily in the past, like education on courts, communication of particular institutions - CT, NCJ, courts - with society, has had a negative impact on the image of the judges and the lack of citizens' engagement thereof.

What has happened in Poland in the period from 1989 to 2015 transformed judges from regime agents of the past to current freedom fighters, despite the lack of widespread lustration. But, there are also opinions that not much has changed. This is a starting point of the governing majority supported occasionally by scholars, who, like Adam Czarnota, see rather a continuity of degeneracy and corruption. ${ }^{250}$ However, this is a somewhat isolated view.

In my opinion, current events prove that a lot has changed. The number of still-active judges in service before 1989 is less than eight percent -746 out of over $10,000 .{ }^{251}$ Therefore, the vast majority of judges were appointed after 1989. Furthermore, most of the judges were already educated based on the legislation of 1989, the so-called small constitution of 1992, and finally, the 1997 Constitution. Therefore, concepts of separation of powers and judicial independence are like oxygen for them. Additionally, judges from courts of lower instances resist themselves and try to mobilize their older colleagues from higher courts. Because of the differences in behavior, the argument that the judicial system duplicated itself and communist judges raised new generations of judges is difficult to prove, even if there are some aspects of institutional path dependency. ${ }^{252}$ One of these differences is precisely the topic of our analysis - the relations of the judiciary with CSOs.

\section{E. Conclusions}

The Polish example shows how important civil society and specialized social organizations can be in the face of attacks on the rule of law, courts and their independence, and liberal democracy in general. It shows that CSOs can play a much broader role in communication between judges and citizens and practical defense of the values under threat. For example, by using strategic litigation designed jointly with judges. The role in a society and the impact of Polish CSOs on the judicial and social resistance is in my opinion, significant. But it is also challenging to understand without a closer look, and it is hard to measure using objective criteria. ${ }^{253}$ The reflection on the role of CSOs should continue, for example on topics like the role of CSOs in the constitutional crisis over the Polish Supreme Court.

\footnotetext{
${ }^{249}$ See PlesKot, supra note 24 , at 48.

${ }^{250}$ See Adam Czarnota, Rule of Law as an Outcome of Crisis, 8 HJRL (2016).

${ }^{251}$ See Opublikowano listę 746 sędziów powołanych przez Radę Państwa PRL. Nadal Orzekają [A List of 746 Judges Appointed by the State Council of the People's Republic of Poland was Published. They Still Adjudicate], TVP INFO (Dec. 6, 2019), https:// www.tvp.info/45654675/opublikowano-liste-746-sedziow-nadal-orzekaja-powolala-ich-rada-panstwa-prl.

${ }^{252}$ See Michal Bobek, The Fortress of Judicial Independence and the Mental Transitions of the Central European Judiciaries, European Public Law (2008).

${ }^{253}$ For interesting work of Stephen Golub in this respect based on field research, see Stephen Golub, Legal Empowerment Evaluation: an Initial Guide to Issues, Methods and Impact (2012), https://namati.org/wp-content/uploads/2012/07/GolubEvaluation-Guide1.pdf.
} 
It is not easy to prove, but I contend that while the Polish Constitutional Tribunal takeover was achieved relatively quickly, the Supreme Court's much more successful defense was largely due to the involvement of CSOs. There is no space for detailed case studies, but this Article marked the difference between the two situations. So, while I agree with most of Marcin Matczak's theses, I do not share his general conclusion of the "inability of the post-communist legal culture to defend itself." 254 At least partially, this defense is taking place, and "the game is not over."

I believe that the Article demonstrates that judicial resistance is at least partly inspired and significantly supported by CSOs. Judges and CSOs jointly struggle to defend courts and have slowed down the pace of governmental "reform" of the judiciary. ${ }^{255}$ According to the announcements, in the first term of office-2015 through 2019-the government was to complete the "reform" of the courts, private media, and social organizations. Yet, court "reform" is not finished, notwithstanding that the government announced restructuring of all ordinary courts, establishing the new ones, and the vetting of judges. ${ }^{256}$ Meanwhile, the takeover of the private media did not start until the second term of office and is still not finished. ${ }^{257}$ Thus, it can be concluded that the resistance of Polish judges and activities of CSOs slowed down not only changes in the judiciary, but also in other areas of life.

Familiarizing judges with CSOs seems to be a process that never ends. ${ }^{258}$ It is imperative to develop a culture of providing and receiving feedback in both directions. CSOs are essential for judges and their communication with society. They are natural intermediaries between judges and citizens, who, as it turns out, may engage in defense of "their courts." Judges should analyze the products of organizations and draw conclusions from them. Organizations should communicate their conclusions in a professional, balanced, constructive way.

It is understandable that judges are cautious, hence, sometimes we talk about cooperation, and sometimes only about interaction or communication. Therefore, CSOs who aspire to cooperate with judges must be impartial, professional, and transparent. Some organizations build their position vis-a-vis judiciary over many years of operation and are appreciated by judges.

It is difficult-if possible, at all-to separate CSO activities from other segments of the legal complex. Not just civil society activists but also attorneys-advocates and legal advisors-and legal academics operate often within the CSO umbrella. But thanks to the common projects and initiatives with judicial associations, the CSOs also include or involve judges and prosecutors. Professors Ewa Łętowska and Mirosław Wyrzykowski have been, often simultaneously, academics, CSO activists, and judges. ${ }^{259}$ Professor Marcin Matczak is an academic and a practicing lawyer, but also a CSO collaborator and de facto daily media commentator. Professor Fryderyk Zoll is an academic and CSO activist. All four professors are known for their papers on the current situation in Poland. Many additional people combine at least two roles: CSO activist and member of a nonjudicial legal profession, academic, or former or even current judge. Therefore, when analyzing the legal complex, someone might be described as a lawyer - advocate or legal advisor-or academic notwithstanding that was acting within a project organized by a CSO.

\footnotetext{
${ }^{254}$ Matczak, supra note 230.

${ }^{255}$ It would be interesting to survey opinions of judges on the role of the CSOs in their resistance. Based on several conversations of the author, it is clear that views differ from underlying very significant role and impact of CSOs, to ascribing little, only auxiliary importance to it.

${ }^{256}$ The idea of flattening the courts' structure - two levels instead of existing three — district, regional, appellate-and the idea of possible vetting of judges in the process of reappointment was already announced-unofficially, without presenting the draft law-by deputy minister Łukasz Piebiak in 2016 during the gathering of Iustitia.

${ }^{257}$ In December 2020, a state-owned company bought a media group, Polska Press, that publishes twenty leading regional newspapers, one hundred and twenty weekly magazines, and five hundred online portals. There are also discussions about attempts by state entities to take over private TV and radio stations. See Poland: State-Run Oil Company Buys Leading Media Group, DW: NEWs (Dec. 8, 2020), https://www.dw.com/en/poland-state-run-oil-company-buys-leading-media-group/a-55859592.

${ }^{258}$ This section borrows from Łukasz Bojarski (2019), Communication Strategy ... at. 42-43.

${ }^{259}$ See Mirosław Wyrzykowski, The Ghost of an Authoritarian State Stands at the Door of Your Home, VeRFASSUNGSBLOG (Feb. 26, 2020), https://verfassungsblog.de/the-ghost-of-an-authoritarian-state-stands-at-the-door-of-your-home/.
} 
The legal complex concept focuses on lawyers, including lawyers heading or acting on behalf of legal or human rights CSOs. ${ }^{260}$ The Polish example shows that not only lawyers or legal CSOs are relevant. Numerous activities described in this Article are undertaken by CSOs that group not lawyers but informed citizens who appreciate the value of the rule of law and judicial independence to protect their rights. Akcja Demokracja, which inspires citizens to write letters to the Supreme Court and delivers them to judges, Obywatele RP, who stay in front of the Supreme Court building with a "Stay" banner urging the judges to resist, and many other organizations engaging in various activities in defense of the rule of law should, in my opinion, be included in the concept of legal complex.

Legal complex activity is also about inspiring, creating strategies together, and building the right atmosphere of resistance and opposing evil. CSOs also help to create a public climate serving judicial resistance. One cannot reliably measure the influence of public awareness and support on particular acts of particular people, but it is one of the elements that convinced judges and others, like academics, to act bravely or not to act opportunistically. For lawyers, some events, activities, and ideas that do not have the character of legal actions, may go unnoticed. Whereas, openness to these initiatives, recognizing and appreciating their role and significance, can help achieve the goals set by lawyers.

I believe that the role of CSOs in Poland is not fully recognized and appreciated-at least publicly. ${ }^{261}$ As shown in the Article, even some judges who became symbols of judicial resistance have exhibited this lack of understanding of the CSO role, for example, Supreme Court First President Małgorzata Gersdorf or members of the "old" NCJ. Most legal academics also do not focus on the role of legal CSOs. Researchers analyzing the rule of law backsliding occasionally refer to specific CSO products, such as studies and reports of think tanks or strategic litigation in a specific case. But sometimes, they seem even not to cite the relevant work of CSOs. This Article recounted the example of an important CSO's work on appointment procedures for CT judges that was overlooked. This and other examples show that cooperation between the world of science and CSOs could be improved.

I believe that the relationship between CSOs and the judiciary, the role of CSOs in defending judicial independence, or judicial resistance, is an exciting research topic. Many related questions, including comparative ones, are worthy of reflection and research. Why are there such significant, as I would tentatively argue, differences between states? Why in some countries do legal CSOs go hand in hand with judges in their joint effort to defend independence, while in other countries, there is no such cooperation-or even no resistance?

Legal scholar Wiktor Osiatyński, who has recognized the role of CSOs, and linked the idea of constitutionalism to the development of the third sector, ${ }^{262}$ has encouraged detailed documentation and analysis of events to better understand the problems we face. ${ }^{263}$ The activities of CSOs described above can help to do this. I hope that this Article inspires academics to make greater use of the output of national CSOs and conduct research that considers the social role of these organizations in the field of the judiciary and the law.

\footnotetext{
${ }^{260}$ See Halliday, supra note 10.

${ }^{261}$ The situation sometimes differs in personal contacts or private encounters.

${ }^{262}$ Wiktor Osiatyński, Human Rights AND their Limits (2009).

${ }^{263}$ The Osiatynski Archive, which bears his name, was created after his death in 2017 in order to fulfill his idea of creating a "chronicle of unlawfulness." See ARCHIwUm OsIATYŃSKIEGO, https://archiwumosiatynskiego.pl/en/.
}

Cite this article: Bojarski $Ł$ (2021). Civil Society Organizations for and with the Courts and Judges—Struggle for the Rule of Law and Judicial Independence: The Case of Poland 1976-2020. German Law Journal 22, 1344-1384. https://doi.org/10.1017/ glj.2021.72 